\title{
«Que de hoy en un año». La oralidad en una mascarada: Los Carochos de Riofrío de Aliste*
}

\section{«What today in a year». Orality in a masquerade: Los Carochos de Riofrío de Aliste}

\author{
M. ${ }^{a}$ Pilar Panero García \\ (Universidad de Valladolid) \\ mariapilar.panero@uva.es \\ ORCID ID: 0000-0001-7346-0778
}

\begin{abstract}
On January 1, a masquerade or «obisparra» called Los Carochos is celebrated in Riofrío de Aliste (Zamora) in which eleven characters, some masked, of which two of them, the carochos or devils, are the ones that give name to the whole through a synecdoche. The pre-theatrical action, although in some moments you can talk about participation theater, it is complex, exciting, bustling and fun and takes place in the streets and in a town square converted into a stage for playful exaltation. The actions are interspersed with preset formulas, parliaments and dialogues, but not closed and with couplets, some of the classical folk heritage and new ones every year. The festival declared of Regional Tourist Interest since 2002 is well known and is disseminated in the networks and in the press, written and digital. We will analyze what space orality occupies against the plasticity of masks in all digital media.
\end{abstract}

Keywords: masquerade, Carnival cycle, Palabras-Clave: mascarada, ciclo de Carnaval, pre-theatricalization, rite, folk song, Aliste, pre-teatralización, rito, canción popular, Aliste, agrarian culture, identity.
RESUMEN: El día 1 de enero se celebra en Riofrío de Aliste (Zamora) una mascarada u «obisparra» denominada Los Carochos en la que intervienen once personajes, algunos enmascarados, de los que dos de ellos, los carochos o diablos, son los que dan nombre al conjunto mediante una sinécdoque. La acción pre-teatral, aunque en algunos momentos se puede hablar de teatro de participación, es compleja, trepidante, bulliciosa y divertida y se desarrolla en las calles y en una plaza de la localidad convertidas en un escenario para la exaltación lúdica. Las acciones se intercalan con fórmulas, parlamentos y diálogos prestablecidos, pero no cerrados y con coplas, algunas del acervo folclórico clásico y otras nuevas cada año. La fiesta declarada de Interés Turístico Regional desde 2002 es muy conocida y se difunde en las redes y en la prensa, escrita y digital. Analizaremos qué espacio ocupa la oralidad frente a la plasticidad de las máscaras en el conjunto de los medios digitales.

\footnotetext{
* Agradezco la ayuda prestada a Isaac Macho Blanco, Juan Francisco Blanco y Alfredo Rodríguez, grandes conocedores y dinamizadores de Los Carochos, que trabajan porque la tradición no solo sea rescatada, sino porque sea reconocida.
} 
Junto al pozo amargo de la soledad, la fronda de la solidaridad. Sigue a Sancho Pueblo, señor Don Quijote. Blas de Otero

\section{INTRODUCCIÓN}

En 1973 un grupo de jóvenes recuperaron durante las fiestas patronales de octubre la mascarada Los Carochos, que se había perdido en los años 60 debido a la emigración ${ }^{1}$. Unos meses después, el 1 de enero de 1974, se celebró la mascarada en la fecha del calendario tradicional, en el que se ha mantenido hasta hoy.

Los Carochos de Riofrío responden con su existencia y vitalidad actual al proceso en el que se ve inmersa la cultura popular que se reinventa, se recrea y masifica, que, en ocasiones, la transforma en productos turísticos. Esta mascarada tiene desde el año 2002 la mención de Fiesta de Interés Turístico Regional, pero más allá de esta circunstancia, la mascarada se percibe en Riofrío como el principal recurso y emblema de una cultura profunda sobre la que hay un amplio consenso ${ }^{2}$ y un interés por conocer el pasado, mantener la tradición y adaptarla al presente mediante diversas iniciativas ${ }^{3}$.

El folklore ya no es propiedad de campesinos aislados que viven en la autarquía, que tienen escasa o nula diferenciación social y que lo preservan de las amenazas del mundo moderno. Los mantenedores de la tradición de Los Carochos no lo hacen desde planteamientos románticos y melancólicos conformándose con coleccionar materiales y ensalzar su fiesta sin más. Hacerlo hoy día así sería un desatino, porque, si bien es cierto

\footnotetext{
${ }^{1}$ Fueron muchas las comarcas que se despoblaron en España en los años 60-70 del s. XX, entre ellas Aliste. Entre 1950 y 1960 más de un millón de personas se desplazaron desde las dos Castillas, Andalucía y Extremadura a Cataluña, Madrid y el País Vasco. La emigración a Europa desde estos territorios en ese mismo periodo se acercó al millón de personas (Sánchez Jiménez, 1975: 80). La pérdida demográfica en la comarca no ha afectado solo a pequeñas poblaciones, sino que se ha sentido en las villas históricas pasando de una población de 41.634 habitantes en 1950 a 20.362 en el año 2000 con «un crecimiento natural negativo, una estructura por edad y sexo desarticulada, un vacío próximo al "desierto demográfico" (menos de 5 hab. $/ \mathrm{km}^{2}$ )» (Méndez Plaza, 2002: 17).

Además de la descapitalización económica, se originó la humana y cultural del medio rural. Sin embargo, a pesar de que ese empobrecimiento, y en algunos casos destrucción, no ha cesado hasta la actualidad continúan vivas algunas formas de vida legadas y aprendidas de la tradición.

La situación actual no es nada halagüeña. Los datos publicados por el Instituto Nacional de Estadística que publica el número de residentes en cada anejo de la provincia en 2020 son: Riofrío de Aliste: 224 (-12), Abejera: 126 (-4), Cabañas de Aliste: 70 (-2) y Sarracín de Aliste: 226 (-20). M.H. «Despoblación en Zamora: Consulta el número de habitantes de tu pueblo», La Opinión de Zamora, 23/01/2020. Véase <https://www. laopiniondezamora.es/zamora/2020/01/23/despoblacion-zamora-consulta-numero-habitantes/1218319. html>

${ }^{2}$ En el logo moderno del Ayuntamiento de Riofrío de Aliste aparecen cuatro elementos con el lema «Tradición viva»: una máscara de un diablo, un aprisco de piedra con bardas para guardar el ganado, la Sierra de la Culebra con el río que le da nombre y un lobo.

${ }^{3}$ La revista Los Carochos editada por la Asociación Cultural «Amanecer de Aliste» publica un número anual en enero desde el año 2013, que sirve de memoria de los logros del año, la relaciona con otras mascaradas, une a mayores y pequeños, indaga en el pasado para conocerlo y tiene vocación internacional. En 2015 se inauguró el museo Casa de Los Carochos y desde 2018 existe la Web desde la que se difunden las actividades y la historia. Véase: $<$ http://loscarochos.es/> Los mantenedores alientan y apoyan a todos aquellos que, además, tienen iniciativas relacionadas con Los Carochos, desde una ópera, una película, exposiciones o una estancia de una compañía teatral profesional como Alkimia 130.
} 
que es útil y necesario conocer el relato etnohistórico para la comunidad y para cualquier interesado en la tradición como un objeto de estudio desde parámetros científicos, la cultura popular hoy no habita en una sociedad controlada y autosuficiente, sino masiva y compleja. El desarrollo moderno no aniquila la tradición, o no necesariamente. Si se siguen los cauces adecuados, los que marca la sociedad en cada momento preciso, la modernización, que hoy día está ligada a Internet, es compatible con la pervivencia de lo popular-tradicional, e incluso lo arcaico del no tiempo diuturno e idílico. Es más, los recursos folklóricos se pueden incorporar con éxito a los circuitos comercialesconsumistas sin menoscabo del proceso de emblematización y patrimonialización a nivel local en el que están inmersas muchas mascaradas en este momento, Los Carochos son un ejemplo claro, como ha demostrado Paula Godinho (2010) que ha analizado el caso trasmontano. García Canclini (1995: 200-203) también nos dio esas claves para los productos folklóricos, en general, en el ámbito hispanoamericano.

\section{LOS CAROCHOS EN EL CONTEXTO DE LAS OTRAS MÁSCARAS ZAMORANAS Y TRASMONTANAS}

La mascarada los Carochos se celebra el día de Año Nuevo durante todo el día. Ésta es una de las diecinueve mascaradas que se celebran en la provincia de Zamora y que admiten diversas clasificaciones basadas o bien en el número de personajes — protagonistas y adláteres —, en la acción o en el protagonismo de la máscara demoniacas, zoomorfas o mixtas - (Rodríguez Pascual, 2009: 25-26; Calvo Brioso, 2012: 34-37). Estas clasificaciones incluyen también las máscaras demoniacas de las botargas al servicio de la liturgia cristiana en el Corpus Christi, pero ahora solo nos vamos a centrar en las máscaras en el ámbito de la provincia de Zamora relacionadas exclusivamente con el ciclo de Carnaval, entendido en el sentido amplio que se conforma desde diciembre hasta febrero con «muchas designaciones e intenciones de las fiestas en el tiempo y el espacio» (Caro Baroja, 2006: 161). Una clasificación sencilla podría dividir las mascaradas de Zamora en cuatro grandes tipos que admiten otras clasificaciones:

1. Zangarrones, cuya principal característica es que son enmascarados fustigadores: los Zangarrones (Sanzoles, 25 y 26 de diciembre, y Montamarta, 1 y 6 de enero) y el Tafarrón (Pozuelo de Tábara, 26 de diciembre).

2. Obisparras, que se componen de varios cuadros escénicos: El Pajarico y el Caballico (Villarino tras la Sierra, 26 de diciembre), los Carochos (Riofrío de Aliste, 1 de enero), la Filandorra (Ferreras de Arriba, 26 de diciembre), los Diablos (Sarracín de Aliste, 1 de enero), los Cencerrones (Abejera, 1 de enero) y la Obisparra (Pobladura de Aliste, 15 de agosto y antiguamente el 26 de diciembre), la Bisparra (Triufé, 31 o 1 de enero), El Atenazador (San Vicente de la Cabeza,11de agosto y antiguamente el 29 de junio).

3. Vacas y toros, en los que el protagonismo recae en una mascarada vacuna o taúrica sea esta mixta como las talanqueiras (mitad humana y mitad animal) o simple (animal): Vacas Bayonas (Almeida de Sayago y Carbellino de Sayago, Carnaval), Vaca Antrueja (Pereruela de Sayago, Carnaval), Toro de Carnaval (Morales de Valverde, Carnaval), la Vaquilla o «Cencerreros» (Palacios del Pan, Carnaval), la Talanqueira (San Martín de Castañeda, 5 de enero), la Bisparra (Vigo de Sanabria, 26 de diciembre).

4. Los Carnavales (Villanueva del Valrojo, Carnaval). 
En Trás-os-Montes se conservan treinta y una mascaradas que se celebran, salvo dos excepciones - A festa da Cabra e do Canhoto en Cidões el 31 de octubre y la Festa de Santa Luzia ou do Velho e da Galdrapa en São Pedro da Silva en torno al 13 de diciembre - entre Navidad y la Epifanía y en Carnaval:

1. El 25 de diciembre: en Bruçó A festa dos Velhos, en Vale de Porco A festa do Chocalheiro (también se festeja el 1de enero), en Valverde O Careto e a Velha, en Pinela A festa do Natal e o Charolo.

2. Por san Esteban, 26 de diciembre: en Aveleda a Festa dos Rapaces (también el 25 de diciembre), en Bemposta O Chocalheiro, en Grijó de Parada A festa de Santo Estêvão, en Ousilhão A festa de Santo Estêvão, en Parada de Infanções As festas de inverno, en Rebordãos A Mesa De Santo Estêvão, en Rebordelo A festa de Santo Estêvão, en Torre de Dona Chama A festa de Santo Estêvão, en Varge A festa dos rapazes (también el 25 de diciembre), en Travanca A Festa da Santo Estêvão (lo celebran el 27 de enero).

3. Por san Juan Evangelista: en Constantim A festa das morcelas ou da mocidade (27 y 28 de diciembre).

4. En Año Nuevo: en Vale das Fontes A festa de Santo Estêvão (31 de diciembre y 1 de enero), en Tó A festa do Santo Menino, en Vila Chã de Braciosa A Festa do Menino ou da Velha.

5. Por la Epifanía: en Baçal A festa dos Reis ou dos rapazes, en Rebordainhos O cantar dos Reis, en Rio de Onor A festa dos Reis, en Salsas A festa dos Reis, en Vilarinho dos Galegos A Mascarão e Mascarinha.

6. En Carnaval: en Alfândega da Fé O Entrudo, en Bragança A Morte, o Diabo e a Censura, en Vinhais A Morte e diabos à solta, en Podence O Entrudo Chocalheiro, en Santulhão O Entrudo, en Vila Boa de Ousilhão O Carnaval.

Aunque haya algunas diferencias, no podemos estudiar las mascaradas de Zamora sin considerar las de Trás-os-Montes que, en conjunto, forman una zona que puede considerarse la más rica de Europa. El territorio es una gran área cultural quebrada aparentemente por las fronteras, pero viva en la que los límites políticos y religiosos no han borrado las constantes culturales. De hecho, la frontera es conocida por los habitantes como La Raya, porque de facto no es percibida como tal. Históricamente se han mantenido relaciones de vecindad compartiendo una misma identidad. La herencia cultural de las comarcas de Sayago, Aliste y Sanabria y de los concejos de Miranda do Douro, Vimioso, Bragança y Vinhais es la misma. Su raigambre leonesa, a pesar de los más de ocho siglos de separación con la frontera política más antigua de Europa, que se configura en los s. XII y XIII como señalan Enrique Clemente Cubillas e Iñaki Martín Viso (véase Hortelano Mínguez, 2009: 18, 20-25).

La densidad de celebraciones de mascaradas en Zamora y Trás-os-Montes tiene un buen exponente en el Municipio de Riofrío de Aliste, que celebra en tres de sus cuatro localidades - Riofrío de Aliste, Abejera y Sarracín de Aliste ${ }^{4}$ - una obisparra el día uno de enero, y está documentado que también se celebró en Cabañas de Aliste hasta los años 60 (González Fernández, 2014: 65-66). En Abejera se dejó de celebrar durante tres o cuatro años y, tras la recuperación, se ha simplificado reduciendo el tiempo de la

\footnotetext{
${ }^{4}$ Puede verse el documental con guion, montaje y dirección de Arturo Dueñas (2019) sobre estas tres mascaradas solsticiales.
} 
performance a poco más de dos horas a primera hora de la tarde para hacerla compatible con las de Riofrío y Sarracín. Esta última se canceló en 2010 y 2011 por diferencias entre los mozos y el Alcalde pedáneo (Calvo Brioso, 2012: 400, 530) y, en el año 2020, hemos constatado que sobrevive porque algunas mujeres jóvenes han interpretado a parte de los personajes, como una mujer también ha representado a la Madama en Abejera. El privilegio antiguo de los varones de participar en las mascaradas ha cambiado y, salvo en algunos lugares donde no ha sido necesario como en Riofrío de Aliste o Sanzoles, la participación femenina se asume con naturalidad en ambos lados de La Raya, A Raia en portugués y gallego.

\section{MASCARADA, TRANSGRESIÓN Y COMUNALISMO}

Muchas se mantienen en Navidad porque, como ha señalado Caro Baroja en su estudio histórico-antropológico publicado en 1965 (2006), también Navidad pertenece al ciclo de Carnaval. Como hemos visto, la mayoría de estas mascaradas se celebran en el llamado «Ciclo de los Doce Días»; es decir, en el tiempo que transcurre entre Navidad y Reyes. Son varias las que se representan en la fecha concreta del 26 de diciembre, fiesta de san Esteban protomártir, diácono organizador de comidas para pobres (Tiza, 2018:41) y patrón de las cofradías de mozos en algunos lugares como Aliste (Rodríguez Pascual, 2009: 21), mientras que otras se celebran el día 1 de enero, otras la víspera de la Epifanía y, algunas, debido a la atonía demográfica se han recuperado de forma extemporánea en agosto, cuando los pueblos albergan a sus emigrantes coincidiendo con el periodo vacacional ${ }^{5}$.

Rodríguez Pascual (2009: 21-22) explica que es muy verosímil que la mascarada específica de san Esteban absorbiese a otras que existían con antelación y que los trajes de obispos «o acaso del diácono Esteban», sirvieron para denominar a muchas mascaradas alistanas como «obisparra». Un ejemplo es la Vaca Bayona en la que una mojiganga relacionada con la organización comunal de terrazgo asimila la verdadera mascarada transgresora, el obispillo, que se prohíbe trasladándose posteriormente, hacía en s. XVIII, a los carnavales (Panero, 2017: 189-195), que han llegado a encarnar el gran triunfo de las máscaras.

En cualquier caso, hablamos de unas celebraciones de naturaleza carnavalesca con rasgos comunes y singularidades propias, expresadas en un riquísimo acervo lingüístico, dependiendo de las localidades en las que participan los actores que representan a diversos personajes grotescos. Estos tradicionalmente eran hombres, los mozos, aunque en la

\footnotetext{
${ }^{5}$ No solo se han hecho recuperaciones extemporáneas -Pobladura de Aliste (Mahíde, Zamora), San Vicente de la Cabeza (Zamora) y, sin continuidad La Torre de Aliste (Mahíde, Zamora) - (Calvo Brioso, 2012: 467, 509, 247), también se han hecho recuperaciones según el viejo calendario folklórico recientemente como la Bisparra de Triufé en 2018, 70 años después de su pérdida, o el Toro de Carnaval de Morales de Valverde en 2017, 20 años después, por poner algún ejemplo. Incluso en Almeida se ha dado el caso de recuperarla en 2005 en la fecha tradicional, Carnaval, después de perderse en los años 90 del s. XX y celebrarla también de forma extemporánea desde 2009, fecha en la que tiene más vitalidad actualmente (Panero, 2017: 201-206).

Se ha hecho la descripción etnográfica de las recuperaciones de Morales de Valverde y Triufé en un inventario actualizado de las mascaradas de Zamora, Trás-os-Montes y una que se conserva en Salamanca — La Bufa de San Antón en Aldeadávila de la Ribera - en el informe Mascaradas de invierno de la Raya Ibérica en el antiguo territorio Zoela / Winter masquerades of Raya Ibérica in the ancient Zoela territory (2019) para la candidatura Intangible Cultural Heritage Section UNESCO solicitado por ZASNET, Asociación Europea de Cooperación (AECT), y elaborado por IDimás Gestión. Equipo técnico: J. L. Alonso Ponga, A. Tiza, M. ${ }^{a}$ P. Panero y C. Sánchez. Inédito.
} 
actualidad muchas sobreviven por la participación de hombres de más edad y por la de las mujeres. Los rasgos comunes de las mascaradas que se conforman con un entramado ritual y simbólico de gran riqueza son: el uso de máscaras elaboradas con distintos materiales como el corcho, el latón, la madera, las fibras vegetales o el cartón; algunos personajes de las mojigangas se cubren con pieles de animales - vaca, ciervo, cabra, oveja, liebre...- - y visten trajes confeccionados con fibras o adornados con elementos vegetales como flores o frutas; llevan un cinturón con cencerros de diferentes calibres en función del personaje atados en la espalda; portan instrumentos para agredir a otros personajes o a los incautos presentes o bien golpeando - con vejigas hinchadas, pelotas compactas,...-, o bien pellizcando, asiendo y picando - con tenazas, tenazas articuladas, cayadas, horcas...e incluso arrojando elementos como ceniza, harina o paja; peticiones de aguinaldo o cuestaciones; y se celebran comensalismos, que pueden ser para todos los miembros de la comunidad sin excepción o para algún grupo concreto de la misma.

Utilizamos el término «ciclo» conscientemente, sabiendo que actualmente «ciclo festivo» es un anacronismo, salvo que se utilice, como es el caso, para referirse a fiestas antiguas relacionadas con el devenir de la naturaleza que permanecen como restos de ceremonias cuyos contextos han desaparecido, pero que se mantienen hoy día en el nuevo calendario laboral resemantizadas. Hasta los años 60-70 del pasado siglo el tiempo astronómico de las tormentas, las sequías y las heladas era el tiempo social que dependía del medio, de las necesidades que la agricultura y la ganadería y de las faenas en torno a las mismas y a los terrenos comunales de pastos y leñas.

Ese comunalismo «de la propiedad y del trabajo, como prueba la costumbre, entre comunista y colectivista» aplicado a las actividades económicas (rozadas, industria pecuaria, industria fabril, ojeo de lobos, recomposición de caminos...) que relata Méndez Plaza $^{6}$ y que hace extensiva a los modos de vida alistanos, «la estrecha solidaridad en la que viven» (2002: 51), también existió en los vecinos territorios portugueses, sayagueses y sanabreses. Aunque lo comunal es hoy anecdótico si lo comparamos con el enorme peso que tuvo hasta bien entrado el s. XX no solo en los aspectos económicos, sino también en los sociales donde «como todas las comunales [las fiestas] a afianzar la mutualidad de relaciones, no interrumpida en todas las manifestaciones de su vida» (Méndez Plaza, 2002: 95) subsiste culturalmente con un cariz netamente identitario ${ }^{7}$. En la mascarada Los Carochos del pasado, cuando alguna familia había caído en desgracia y no tenía matanza los mozos repartían parte de su aguinaldo (Rodríguez Pascual 2009:141). Actualmente esta costumbre solidaria, como la de no pedir en las casas que guardaban luto, tiene su representación cuando los Carochos ofrecen chorizo a la gente en el baile del «Sagrao» (frente a la iglesia parroquial). Y todavía esta costumbre antigua se resemantiza de nuevo cuando se estiliza como parte de un espectáculo no popular. La última actualización pudo verse en la ópera La Obisparra, creada por el compositor Daniel Blanco Albert y estrenada en marzo de 2016 en Birmingham con 40 músicos y actores ante un público británico que desconocía la tradición (Blanco Albert, 2017). El compositor quería trabajar

\footnotetext{
${ }^{6} \mathrm{Su}$ obra es una Memoria que obtuvo el accésit en el primer concurso especial sobre Derecho Consuetudinario y Economía Popular abierto por la Academia de Ciencias Morales y Políticas para el año 1897.

${ }^{7}$ Por ejemplo, en Bercianos de Aliste, a 13 kilómetros por carretera y 6 en línea recta, se conserva la costumbre de celebrar El Antruejo el domingo anterior a de Carnaval, que es la llamada que se hacía a toque de campana para limpiar los comunes de la orilla del río, aunque se pueden adecentar otros espacios, y en la que participan todas las familias representadas por algún miembro. Finalizados los trabajos se culmina con un banquete para todo el pueblo.
} 
«algo que reflejara todo ese rico patrimonio cultural, pero sin el paternalismo que tiene a veces la composición tradicional» y para ello contó con las canciones tradicionales de Aliste, el sonido propio de las mascaradas - cencerros y tambor-, los trajes y algunos atributos originales que le enviaron desde Riofrío y elementos del rito llamativos como afirma en una entrevista:

¿También utilizasteis ceniza?

No, ceniza no. Nos lo impidieron, pero, sin embargo, sí pintamos a gente con las corchas. Al Diablo Pequeño yo le había dado la instrucción teatral de que en determinado momento tenía total libertad para pintar a la audiencia con las corchas. ¡Y hasta le dimos chorizo al público!

¿Lo mordían?

Sí, sí, jclaro que mordían! Aunque, en nuestro caso el chorizo lo daba el Ciego de Atrás en lugar de los Diablos. Fue una pequeña licencia teatral. Tuvimos que cambiar un poco la historia final para darle un dramatismo diferente... ${ }^{8}$

Las mascaradas eran fiestas relacionadas con una concepción antigua de la transgresión, hay acciones análogas a las que se suceden en Carnaval, que se llevaba a cabo mediante rituales de inversión o propiciatorios para los que puntualmente había licencia y que, en general, tienen paralelismo con las fiestas romanas como señaló Caro Baroja (2006: 162-163). Las fiestas romanas relacionadas con la mayor parte de las mascaradas zamoranas y trasmontanas son: las Saturnalia en honor a Saturno, dios de la agricultura, entre el 17 y 21 de diciembre; las Kalendae Ianuariae en honor Jano, Ianus, que en la mitología romana, es el dios de las puertas, los comienzos, los portales, las transiciones y los finales; las Compitalia, que se celebraban el 4 y 5 de enero; las Lupercalias el 17 de febrero para propiciar la salud y fecundidad de los animales; y las Matronalia que se celebraban el 1 de marzo para asegurar la fecundidad de las mujeres. De ellas descienden las fiestas de los obispillos, las mascaradas, las Candelas y san Antón Abad y las de santa Águeda respectivamente.

Sin embargo, en consonancia con Caro Baroja (2006), no sostenemos que las fiestas actuales sean la evolución del calendario romano, o solo del romano, pues a lo largo de los siglos en los que se han desarrollado, la Iglesia históricamente ha intentado controlarlas a través de las cofradías vinculadas a los santos, especialmente las dedicadas a san Esteban. En el territorio se implantó pronto una religión dogmática, el cristianismo, y «hay que aceptar que en la fijación del calendario los cristianos han aceptado una tradición antigua y que ésta se ajusta a conceptos acuñados por sociedades paganas» (Caro Baroja, 1978: 334).

Tampoco podemos obviar que este territorio fue marginal en las provincias romanas Transduriana - Aliste, Sanabria y los concejos de Miranda do Douro, Vimioso, Bragança y Vinhais - y Hispania Ulterior en la que está Sayago hasta el año 15 a. C. en que se suprimió como señala Manuel Salinas de Frías (véase Hortelano Mínguez, 2009: 153-161). La zona alejada tuvo una romanización lenta y poco profunda propicia para mantener un sustrato cultural prerromano precelta y celta, que algunos investigadores ven en muchas mascaradas portuguesas (Tiza, 2013: 30, 118-124; Tiza, 2018: passim) y en algunas zamoranas como El Caballico y el Pajarico (Tola Tola, 2015: 7-8). Realmente el campesino apegado a la tierra de la que depende, es profundamente religioso y va

\footnotetext{
${ }^{8}$ Véase la entrevista en: $<$ http://loscarochos.es/dani-blanco-la-obisparra-en-birmingham/>
} 
adaptando su discurso en función de lo que sea sagrado en cada momento, pero permitiendo que sobrevivieran elementos paganos tras la conversión al cristianismo.

En otra de las reactualizaciones recientes, el rodaje del cortometraje Galo, la leyenda de Los Carochos en 2015 por un estudiante de la Escuela de Cine de Barcelona, Manuel Garrote Franco, en el argumento se juega con el pasado «pagano» de la mascarada. El testimonio se basa en que la tribu de los diablos vive oculta en el bosque para burlar a la Santa Inquisición. El día del bautizo de La Madama (Gala) es maldecida por Los Carochos (Asmodeo y Azazel) para que en su vigésimo cumpleaños quede encinta del Maligno, sin embargo, ese día nace El Galán (Galo), hijo de El del Tamboril (Tomás) que convenientemente entrenado por El Ciego el día señalado hará que la Luz venza a la Oscuridad (Garrote Franco, 2015; Gago, 2016: 10).

Nosotros, siendo muy conscientes de que la tradición se construye, sobre todo, desde el presente, suscribimos las palabras del académico y coleccionista de máscaras Roberto Afonso, que citando al antropólogo gallego Manuel Mandianes, dice: «Es absurdo buscar los orígenes históricos del Carnaval. Pueden encontrarse los orígenes de este o aquel traje, de esta o aquella máscara; el origen del Carnaval es tan antiguo como el culto a los antepasados: la noche de los tiempos... $\rangle^{9}$. En el caso que ahora nos ocupa hay elementos que han cambiado que están perfectamente documentados como la caracola, que usa uno de los personajes, El Molacillo, algunos trajes y otros elementos del atrezo.

En los años 50 sustituye al cuerno, el mismo que utilizaba el alcalde de mozos para convocar a las juntas, por una razón de lo más prosaica: un emigrado a Levante importó la caracola «sin que ello causara ningún trastorno», porque realmente el sonido es parecido (Blanco González, 2020). En el año 1978 no disponían de trajes tradicionales por lo que el joven que encarnó al Galán lo hizo con un traje azul de la época comprado ex profeso para la ocasión, mientras que otro, en otro año, lo hizo con uno de pana marrón ${ }^{10}$. El cambio de elemento no merma lo genuino en la fiesta pues lo importante es el uso y la función y, de hecho, muchos de los atributos más importantes de muchas mascaradas, las máscaras, han sido fabricadas recientemente. Recuerdo las palabras de un artesano portugués, Carlos Ferreira, que en 2019 me confesaba con orgullo que algunas de sus máscaras estaban «ritualizadas». Es decir, que su trabajo no solo tenía una función comercial, sino que también se incardina en la tradición sociabilizadora del rito, que es la que realmente le aporta valor simbólico que va más allá de la materialidad del objeto.

\section{LA PRE-TEATRALIZACIÓN}

En las dramatizaciones de la experiencia colectiva, y en las mascaradas como rito que se celebra en un lugar y tiempo concretos, participa toda la comunidad y actualmente los turistas-espectadores. Sin embargo, las costumbres no son repertorios de prácticas fijas (García Canclini, 1995: 204), porque nos adentramos en el dominio en el que el grupo se manifiesta como tal y utiliza aquello que quiere que prevalezca utilizando los elementos que estima perdurables, pero cambiando o desechando otros accesorios e, incluso, añadiendo novedades que a su vez generan folklore. Esto, que sigue vigente

\footnotetext{
${ }^{9}$ Roberto Afonso, «La valoración de las mascaradas de Trás-os-Montes como Patrimonio Cultural Inmaterial. De los Santos a las Cenizas», conferencia impartida en Simposio Patrimonialización de las mascaradas y su valoración como Patrimonio Cultural Inmaterial, Alcañices (Zamora), 31 de mayo de 2019 celebrado en el Ayuntamiento de Alcañices y organizado por ZASNET (AECT), IDimás y la Cátedra de Estudios sobre la Tradición (Universidad de Valladolid). Comunicación oral.

${ }^{10}$ Testimonios recogidos en la revista Los Carochos, 7, p. 12 (s. a.)
} 
hoy, sucedía a finales de los años 70 del pasado siglo: «es falso que el folklore se haya producido en el pasado y que lo que queda hoy consiste en supervivencias fragmentarias, de modo que lo folk hoy no produce nuevo folklore» (Caro Baroja, 1967: 7).

De hecho, las mascaradas, y esta no es una excepción, además de su representación ritual en su lugar natural, el espacio urbano de Riofrío de Aliste, en un contexto social, religioso y cultural concreto ante personas con competencia cultural para entender la representación dada por la costumbre; hoy día se muestran en otros espacios urbanos y lejanos en los que el público, en general, o bien es ajeno a estas celebraciones o tiene una percepción difusa de la cultura de la máscara ${ }^{11}$.

Nos referimos a los animados desfiles y concentraciones de máscaras, que son un fenómeno extendido más allá del territorio zamorano y trasmontano en todos los lugares en los existe una larga tradición de máscaras ${ }^{12}$, que, tienen la virtud de darle visibilidad y protagonismo mediático a comunidades pequeñas y la posibilidad de relacionarse y unirse a otros grupos de máscaras. Esto se logra rápidamente mediante las formas modernas de comunicación, sobre todo a través de las redes sociales, plataformas para colgar audiovisuales y los anuncios previos y pequeñas crónicas que se publican en la prensa, especialmente en la digital, pero también en las páginas Web oficiales de las instituciones ${ }^{13}$.

En estos circuitos la exhibición de las máscaras se hace desde un punto de vista teatral, de performance folklórica según los clichés actuales de lo que es la cultura popular, idealizándola y estetizándola, la máscara es un objeto bello, pero descartando lo esencial, lo ritual. El arte popular, sin embargo, no es una concentración o colección de objetos y, por lo tanto, lo popular no se debe centrar, o al menos no solo, en las máscaras, los atributos de los enmascarados y la indumentaria. Este cambio no solo se produce por la falta de conocimiento de los espectadores-turistas, sino por los propios componentes de la mojiganga que, lógicamente, son muy conscientes de que actúan para un público heterogéneo que no les da las mismas respuestas que le daría en su comunidad ejecutando el rito completo para los no espectadores-turistas, sino para sus vecinos, amigos y parientes. La información en un desfile se hace accesible a todos y se basa en la universalidad de la máscara, todas las culturas la tienen, pero, al darse de manera sesgada, oculta las

${ }^{11}$ En los desfiles se mezclan máscaras pertenecientes al ciclo de Carnaval con un origen impreciso y relacionadas con unos ritos de fertilidad y purificación, con máscaras asociadas a la celebración del Corpus Christi, con un origen muy concreto, las representaciones teatrales del Renacimiento, y una finalidad ritual en origen distinta. En las noticias y crónicas acerca de los desfiles el segundo tipo de máscaras que aparecen en la prensa o en blogs de viajes, en ocasiones se asocia la máscara al Carnaval sin más y, por ejemplo, pueden aparecer erróneamente El Colacho de Castrillo de Murcia o los Hombres de Musgo de Béjar como manifestaciones del Carnaval tradicional. Véase el artículo Haritz Rodríguez (2016): «30 Carnavales tradicionales de Europa», en <http://tokitan.tv/carnavales-tradicionales-europa-ancestralesrurales\#comments $>$. Evidentemente este ejemplo no es una crítica al autor, que hace un esfuerzo por recabar muchísima información, pues es fácil esta confusión tal y como se difunde la información a través de vídeos en Youtube, en Isntagram, etc.

${ }^{12}$ Por ejemplo, en Guadalajara, donde participaron 32 localidades con sus botargas y se unió la vaquilla de Frenadilla de la Oliva (Madrid). Véase, Las botargas toman Guadalajara-Ancha es CLM-CMM (2019): $<$ https://www.youtube.com/watch?v=ml39BqPaebA>

${ }^{13}$ Por ejemplo, en la Web de la Xunta de Galicia se anuncia, acompañado de preciosas fotografías que ilustran la información, «Desfile de Carnavales Tradicionales de Galicia», donde se explica que «El día 7 de septiembre habrá una posibilidad única de admirar la variedad y la autenticidad de los Carnavales Tradicionales de Galicia. La cita es a partir del mediodía en la Praza do Obradoiro para continuar por las principales calles y plazas del casco viejo de Santiago de Compostela»: $<$ https://www.turismo.gal/quefacer/promocions-para-gozar-agora/desfile-de-entroido?langId=es_ES> 
relaciones locales entre los grupos de edad y sus jerarquías, incluida la que tienen con el poder religioso, es decir, se esconde el componente socializador del rito.

Independientemente de los beneficios y perjuicios que estas acciones tengan sobre los territorios y sus gentes, que no es el motivo de este artículo, aunque se pueden leer algunas de las reflexiones que hace al respecto el antropólogo José Luis Alonso Ponga ${ }^{14}$ se está produciendo una simplificación poniendo el acento en lo meramente visual haciendo referencia a la máscara en general y obviando los elementos de la máscara en particular más allá de lo descriptivo, léase colorista o pintoresco.

Los Carochos también han participado del proceso de folklorización general de la cultura tradicional (Martí i Pérez, 1996: passim) y, solo en el año 2013, participaron en cuatro concentraciones y desfiles - en febrero en Bragança, en mayo en Lisboa, en julio en Alija del Infantado y en septiembre en Zamora (Rodríguez, 2014)_-, en 2014 viajaron a Tolmezzo en la región de Carnia en el norte de Italia (Blanco Sutil, 2015), en 2015 en León, Zamora y Bragança y en 2017 en Zamora.

Los protagonistas de Los Carochos, todo el pueblo de Riofrío sin excepción, también han participado de una teatralización, lejos del lugar dado por la práctica, concretamente en X Bienal de Restauración y Gestión del Patrimonio (ARPA) celebrada en Valladolid en 2016 (Hidalgo Blanco et allí, 2017). Se hizo una representación dramática, pero considerando gran parte de los cuadros del rito, incluidos los orales, que nunca están en los desfiles. Esta teatralización fue un juego en el que participantes y público intentan mostrar y conocer la tradición sin las veladuras que provocan las concentraciones masivas.

Existen varias descripciones de esta mojiganga parateatral Los Carochos que la tratan en el conjunto de otras mascaradas zamoranas (Rodríguez Pascual, 2009: 122-156) o castellanoleonesas (Calvo Brioso, 2012: 487-498), y una monografía específica que indaga y describe densamente todos los detalles (Blanco González, 2004). Ahora haremos una breve descripción de los personajes y de las acciones, pero por su naturaleza basada en un dinamismo colectivo y, en la arriba citada, capacidad de recreación y reinvención, seguiremos el trabajo de Juan Francisco Blanco considerando algunos cambios constatados con el trabajo de campo que realizamos en la celebración del 1 de enero de 2020.

\section{Los personajes}

Son once los personajes, doce si se considera al Niño de La Madama, que intervienen agrupados o en solitario y, como hemos dicho, representados por varones jóvenes, puesto que el colectivo de mozos con las funciones antiguas no existe. Se dividen en tres grupos más un personaje que va por libre sin adscribirse a ninguno: el de los diablos (o Los Carochos) —Diablo Grande y Diablo Chiquito-, el de los gitanos o filandorros y los ciegos -El Gitano (o El Filandorro), La Filandorra (o La Gitana), El Ciego (o El Ciego de Atrás) y El Molacillo (o El Ciego de «Alante») —, el de los guapos —El Galán, La Madama, El Niño (es un muñeco), El del Cerrón y El del Tamboril- y El del Lino que va por libre sin adscribirse a ningún grupo concreto.

Los dos diablos visten de negro con camisa y pantalón y chaqueta de pana. Ambos se tiznan las partes de su cuerpo visibles, la cara y las manos, también de negro y calzan botas y leguis de cuero. En la espalda llevan unos cintos cruzados con cencerros que se fijan en la espalda con fajas negras con un solo nudo en el pecho, el Diablo Grande, y cencerras que se fijan con unas cuerdas de esparto anudadas del mismo modo que las del

14 Véase la entrevista en: <http://loscarochos.es/jose-luis-alonso-ponga-comisario-de-la-exposicionmascaras-en-accion-los-carochos/> 
compañero, el Diablo Chiquito. El principal lleva seis o siete cencerros en función de su corpulencia, mientras que el diablo ayudante lleva entre doce y quince cencerras.

El atributo del Diablo Grande, y lo más distintivo del personaje, son las tenazas extensibles de color rojo rematadas en cuernos de cabra. Pero lo más llamativo es su máscara o carocha confeccionada principalmente con corcho reciclado de una colmena vieja, pintada de negro, con agujeros para los ojos y boca, dientes de hojalata pintados de blanco, nariz de hojalata pintada de rojo como los labios que están rematados por dos colmillos de jabalí. Los cuernos de la parte superior de la máscara también son corcho y también están pintados de rojo en la punta y el resto de negro. La máscara tiene una perilla confeccionada con cerdas de la cola de una yegua y por la espalda le cae una piel de oveja ribranca, piel negra con el rabo blanco. En la parte superior de máscara o carocha lleva un bote de humo de los que se utilizan en las obras de teatro y otros espectáculos, que se prende en su salida generando una gran humareda que hace su primera aparición espectacular. Antes se utilizaban mechas de las que se conectaban a la pólvora como medida de seguridad en las canteras de pizarra, pero la única que hay moderna se utiliza sistemas más sofisticados.

Los atributos del Carocho Chiquito son, además de los cencerros que caen sobre un mullido de zarzas para que no lo lastimen al golpear, a veces se denomina como «el de las zarzas», una mochila para recaudar aguinaldos como su compañero y dos corchas quemadas con la que tizna el rostro de todos los que estén a su alcance. Este diablo no utiliza máscara propiamente dicha; pero en gran parte de la pre-teatralización no se le ve el rostro de su intérprete, porque le cae por la cara y la espalda una gran melena de pelos de caballo y de rabo de vaca que hacen las veces de máscara peluda. Este tocado se remata con orejas de liebre.

La familia de los filandorros o gitanos parece homogénea pues después de la caída del Ciego, El Gitano se lamenta de la muerte de su abuelo, y El Molacillo denomina hermano al Ciego, aunque el parentesco es fingido pues, si bien El Gitano y La Filandorra son una pareja de gitanos, no hay nada que haga pensar que El Molacillo y El Ciego pertenecen a la misma etnia. El atributo común del grupo que constituye «una comunidad de intereses» más que «un núcleo familiar en sentido estricto» (Blanco González, 2004: 108) es el carro para vacas tirado por burros e incompleto, pues le faltan las costanas por lo que hace las veces de plataforma sobre ruedas. En el carro llevan una «naspa» o «enaspa» (aspa), que es una devanadera para hilar las mazorcas de lino o de lana enrolladas en el huso para convertirlas en madejas de hilo (Cotera, 1999: 493-545). A este grupo se le conoce como «filandorros» porque una de sus misiones es hilar.

El Molacillo es un militar que viste de blanco con faja roja y calza unas botas. Su rostro también está pintado de blanco, antiguamente se utilizaba harina. Se cubre la cabeza con un tocado que es una especie de morrión decorado con mensajes transgresores o de crítica social y desnudos que se remata con plumas y flores. Además, porta una pica roja rematada en aguijón de hierro y una tralla. También lleva dos mochilas cruzadas en las que guarda la caracola y conchas, que también le servirán para recaudar los aguinaldos.

El Ciego viste ropas viejas y raídas. Se cubre con una especie de capa muy burda que le tapa la cabeza confeccionada con un saco de arpillera, y cuya caperuza se remata con tiras largas de papel que caen sobre la nuca y parte de la espalda. No utiliza máscara, pero es difícil apreciar su rostro pues, aunque en 2020 no se cubierto con barbas blancas como hacía en el pasado, lleva unas gafas de corcho tosquísimas que le dan un aspecto hipermiope por su forma casi cónica y va embozado. En 2020 no llevaba en su capa cosidos numerosos gamones, planta de la familia de las liliáceas, en forma de cruz como era habitual en el pasado (Blanco González, 2004: 128) y estos últimos años, pero lleva 
en su mano la cruz de madera. Su atributo principal es un instrumento rústico llamado «corcho» por el material principal en que está confeccionado, que es una especie de zanfona, y un cuerno de vaca que lleva colgado del cuello.

El Gitano, que es más desvergonzado de todos los personajes, debe tener vis cómica y labia para que la mojiganga sea un éxito. Viste chaqueta y pantalones de pana, desgastados y llenos de remiendos de vistosos colores y estampados. En 2020 no ha utilizado la pelliza, ni ha llevado la cara y las manos tiznadas de negro, ni se ha pintado bigote. Su tocado es un sombrero de paja lleno de agujeros y su calzado unas abarcas o botas también con agujeros. Sus atributos son: un reloj de madera; una bota de vino; la «pelota», que es una especie de látigo compuesta por una vara de la que pende una cuerda que termina en una raíz de brezo forrada con trapos viejos, y que emplea para defenderse de los diablos, más bien amenazarlos, y golpear la tierra; navaja o tijeras de esquilar para intimidar; una mochila para guardar aguinaldos; una albarda o alforjas de fibra vegetal que son el aparejo de un tercer burro (los otros tiran del carro) que va por libre y al que intenta montar a veces simulando poca pericia y cayendo para provocar la risa; y antes, porque actualmente no las lleva, unas vejigas de cerdo hinchadas como globos para golpear al público (Blanco González, 2004: 144-145). Después de la primera pelea entre los filandorros y los diablos en el «Sagrao», pero más tarde de lo que lo hará su compañera, La Filandorra, El Gitano se convierte en El Filandorro cambiando sus ropas viejas por un pantalón, chaqueta y gorro confeccionado con tiras de papel de colores.

La Filandorra aparece vestida de gitana con una falda larga de volantes, chambra colorida o camisa que hace las veces, ambas remendadas, pañuelo merino en la cabeza, chal de lana de un color llamativo, y enjoyada con pendientes, pulseras y un enorme collar de buyacas, los frutos del roble. Sus atributos son el huso y la rueca y una cesta de mimbre con abalorios que porta para vender. Inmediatamente después de la primera pelea se transforma y viste un traje hecho con tiras largas de papel y porta un caldero, antes un «avantal» o mandil, con ceniza que esparce entre todos los desprevenidos. Aunque esta indumentaria es muy parecida a la del Gitano cuando se transforma, se la reconoce fácilmente porque sigue llevando el collar de buyacas y el recipiente con la cernada.

Los guapos, que encarnan a la comunidad, frente a los diablos (démones), seres intermedios entre dioses hombres, y los gitanos que son forasteros, van ataviados con los trajes tradicionales festivos de Aliste, aunque, como hemos visto, no siempre ha sido así, o no ha sido igual para todo el conjunto. Actualmente hay algunos cambios, por ejemplo, las preciosas camisas de cabezón se pueden sustituir por camisas de algodón modernas en algunos casos, los zapatos de oreja por calzado actual o las collaradas de coral por imitaciones de plástico sin que actores y espectadores pierdan la ilusión de que el atrezo es antiguo.

El Galán va tocado con la montera y viste camisa de cabezón y chaleco ya sin el jubón (Blanco Rodríguez, 2004: 90), bragas o calzones, medias, zapatos y faja, que se dispone como una banda cruzando el pecho y no rodeando la cintura como distintivo de dignidad. Sus atributos son una vara a modo de cetro coronadas con colonias de colores y unas castañuelas.

La Madama, que va siempre a la derecha del Galán, va tocada con un pañuelo merino anudado en la frente, camisa, mantilla, manteo, «vantal» o faltriquera, mandil, medias, zapatos y enjoyada con collares imitando a los antiguos de coral y pendientes de calabaza de plata. Su atributo es El Niño ataviado como los niños alistanos del pasado con gorro de crista o de perifollo, corbata para ayudarlo a sostener la cabecita, mangos, babador o babero, camisica de lienzo o de lino, pañal, mantilla y fajero. 
El del Tamboril viste como El Galán y su atributo es un tambor pequeño que toca en su pasacalle cediéndoselo a músicos más virtuosos en el baile final. El del Cerrón se llama así porque porta un gran cerrón o zurrón. Viste como el resto de los guapos, pero se distingue porque encima lleva una casaca o anguarina, gabán largo confeccionada con paño casero pardo y sin cuello, con mangas y con botones ${ }^{15}$.

El del Lino encarna a un pobre, pero, a diferencia de los filandorros, no es un pobre forastero, sino local, alistano que está solo como reza en las estrofas de un romance compuesto por el poeta local Agustín Rodríguez:

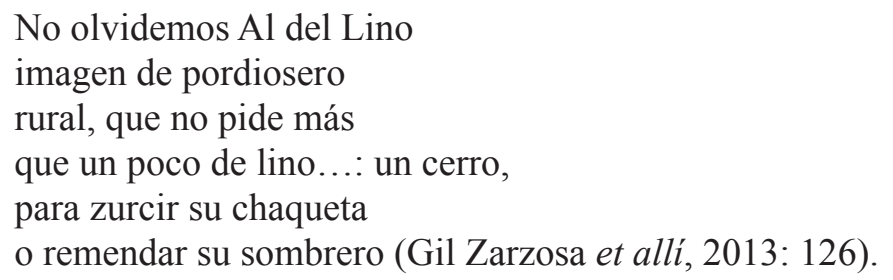

Viste como los menesterosos con camisa de lino burda, sin ornamento y, por supuesto, desgastada, chaqueta corta o jubón, bragas y calza unas cholas. Su nombre se debe a su principal atributo, un cerro de lino, que era el aguinaldo que le daban sus vecinos, y que hasta los años 60 fue un cultivo habitual en la zona. Además, tiene otros dos atributos, la esquila de vacas o terneras que lleva en la espalda y una "cayata», cayado tosco. Lo más llamativo del personaje ahora mismo es una innovación de la segunda mitad del s. XX, cuando se sustituyó la tradicional montera de piel de liebre o de conejo por una máscara también de piel $^{16}$.

\section{Las acciones}

Actualmente los preparativos son más rápidos y menos ceremoniosos que antaño, cuando la mascarada la organizaba el colectivo de quintos y solo elegían personaje los que sacaban el pan bendito. Ahora son los jóvenes solteros que están en la diáspora, estudiando o trabajando, los que se coordinan para la representación. Desde hace unos años ha retrasado la hora de comienzo a bien entrada la mañana y no al alba. El atrezo de los personajes pertenece en parte a la comunidad, ya no hay que solicitar días antes, por ejemplo, los cencerros a los pastores (Blanco Rodríguez, 2004: 166-170), aunque algunos trajes como el de papeles de los filandorros hay que confeccionarlos cada año. Personas mayores y expertas y algunas mujeres jóvenes que se encargan del maquillaje preparan a los personajes en un mismo local, especialmente a los diablos, porque colocarles los cencerros y cencerras es una tarea compleja (Figura 1). Cuando los once personajes están listos entran los tres burros en el local y se los apareja. Después se comprueba que todo

\footnotetext{
${ }^{15}$ Para una descripción exhaustiva de las prendas puede verse los espléndidos trabajos de Gustavo Cotera (1999) y de Agustina Calles y Carmen Ramos (2010).

${ }^{16}$ Juan Francisco Blanco (2004:159-160) explica este proceso: «Al decaer el uso de la montera en el primer cuarto del pasado siglo, el tocado de este personaje sufrió una transformación radical conservándose únicamente el material con el que se confeccionaba: la piel de la liebre, variando la forma sustancialmente. En las últimas décadas consiste este gorro en varias pieles de liebre cosidas que caen sobre la espalda, conservando las orejas enhiestas en lo más alto, cubriendo la cara con fibras de lino, cuerdas de pita deshilachadas o alguna máscara horrible. Más recientemente se ha dotado al personaje de una careta de piel de oveja con una apariencia similar al Carocho Grande lo que en gran medida desvirtúa la esencia misma de este sujeto, que al fin y al cabo no es más que un pobre que pide limosna».
} 


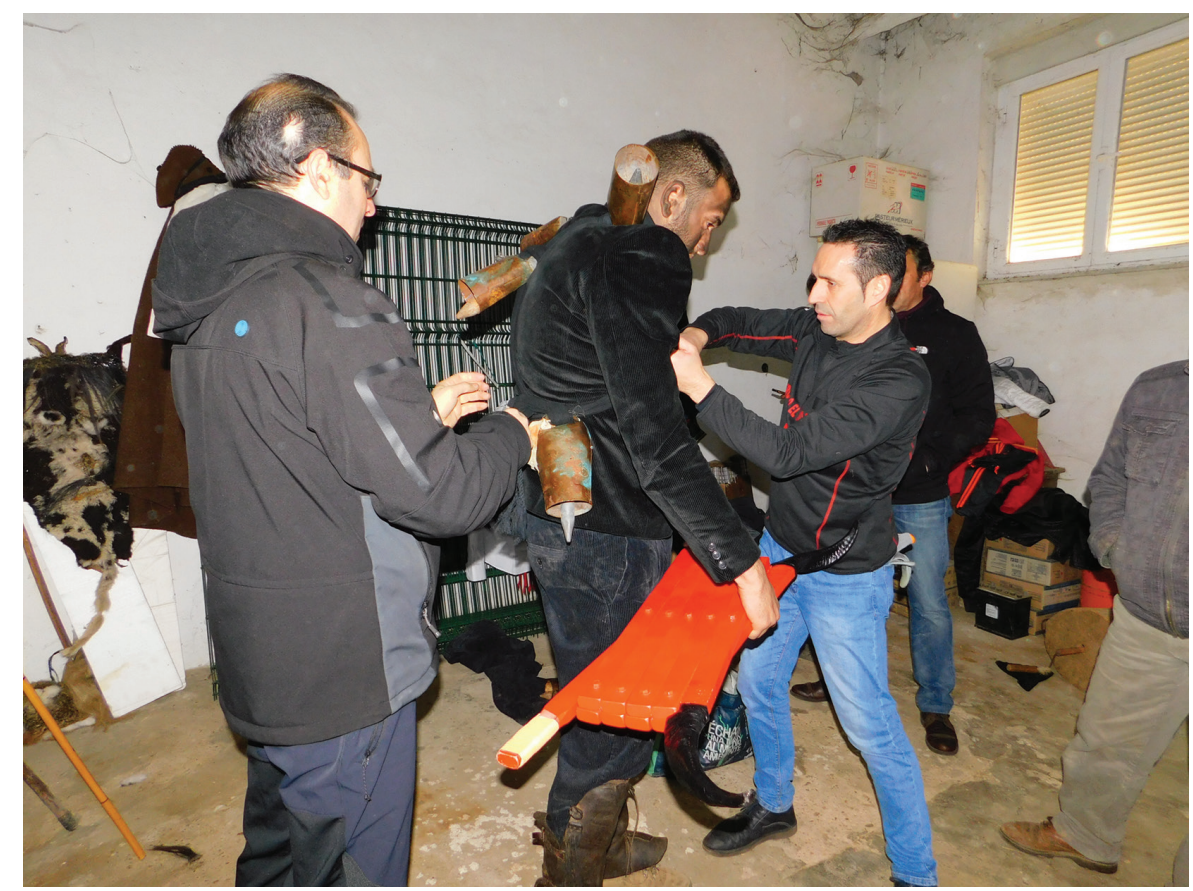

Figura 1: Los expertos preparan al Diablo Grande poniendo especial cuidado en que los cencerros no lo lastimen al golpear. A la izquierda se ve la máscara que utiliza el personaje El del Lino. Fotografía: Pilar Panero, 2020.

está en orden se lanza el cohete que anuncia la salida de la comitiva en este orden: los diablos, los guapos, El del Lino y los filandorros.

La salida es espectacular en una de las calles principales, la calle Fonda, porque aparecen los dos carochos dando saltos, corriendo a gran velocidad y soltando el humo de los dos bores. El Chiquito grita y el Grande mueve las tenazas articuladas. En un momento dado el Chiquito deja al Grande y un poco más tarde se juntan en la misma calle, pero se vuelven a separar y el Chiquito hace una venia frente a la iglesia parroquial sometiéndose así al poder divino.

En el pasado los diablos continuaban con sus gritos y saltos mientras iban a la casa del cura y del alcalde a pedir licencia para hacer la función, pero actualmente esta parte se ha simplificado y si no está en el itinerario, serán los representantes del poder temporal y eclesiástico los que saldrán al encuentro para que les hagan la petición de licencia. Los guapos que van detrás harán lo mismo.

El Galán sale tocando las castañuelas, El del Tamboril lo acompaña con su instrumento y La Madama va arrullando al Niño. Detrás de ellos va El del Lino, renqueante con su cojera y acosando a las mujeres con su cayado como puede, pues estas ya no visten manteos como antaño para levantárselos.

Inmediatamente después va el grupo de los ciegos guiado por El Molacillo, que recibe el nombre de Ciego de «Alante» por guiar el carro en el que van subidos La Filandorra, que va hilando o haciendo madejas, y El Ciego de «Atrás» en la parte trasera con las piernas colgando y desganado leyendo, a pesar de ser ciego, una publicación erótico-pornográfica y de ahí que la copla que entona El Molacillo rece:

Estos ciegos no son ciegos (bis)

que tienen la vista clara.

La boca llena de dientes, (bis)

para comer la tajada. 
Mientras tanto El Gitano monta el tercero de los pollinos haciendo cabriolas y apeándose de forma cómica por lo que se cae para provocar la risa en el respetable. Un poco antes de llegar a la plaza del «Sagrao» un vecino en representación de todos, los retiene inmovilizando su carro. El Molacillo intenta escabullirse, pero no lo logra y aparece El Gitano en su ayuda. El vecino les hace un interrogatorio acerca de su origen, intenciones, actividades, licencias, documentación, etc. produciéndose una conversación disparatada (Figuras 2 y 3 ). Cada uno de los personajes continua con las acciones que le son propias hasta llegar a la casa del cura donde se bautizará al Niño. El bautizo simbólico lo celebra un sacerdote real, este año lo celebró el P. Benicio que nació en Riofrío, y esta parte del ceremonial se celebra con toda la naturalidad como si fuese un sacramento verdadero, aunque todos saben que es una farsa. El padrino, El del Cerrón, tira caramelos como todavía se hace en muchos pueblos. El Niño de La Madama por el bautismo queda protegido de las fuerzas malignas de forma simbólica, porque los diablos sí molestarán a los guapos a lo largo de la jornada (Figura 4).

Concluye el bautizo y los primeros que se van son los diablos apostándose cerca del «Sagrao» a esperar su próxima intervención (Figura 5), le siguen los guapos tocando las castañuelas y el tamboril, El del Lino levantando los abrigos de las mujeres y enganchándolas con el cayado, El Molacillo guiando el carro y El Gitano en su burro haciendo cuantas sandeces se le ocurren hasta que llegan todos al «Sagrao». Allí El Molacillo intenta vender lotería, calendarios..., cualquier cosa y El Gitano el burro, la collera, la albarda... produciéndose conversaciones jocosas con potenciales compradores. La Filandorra también intenta colocar entre la gente su mercadería.

Unos vecinos vuelcan el carro con El Ciego subido, por lo que queda tendido en el suelo maltrecho, mientras La Filandorra consigue escapar y desaparece. El Molacillo y El

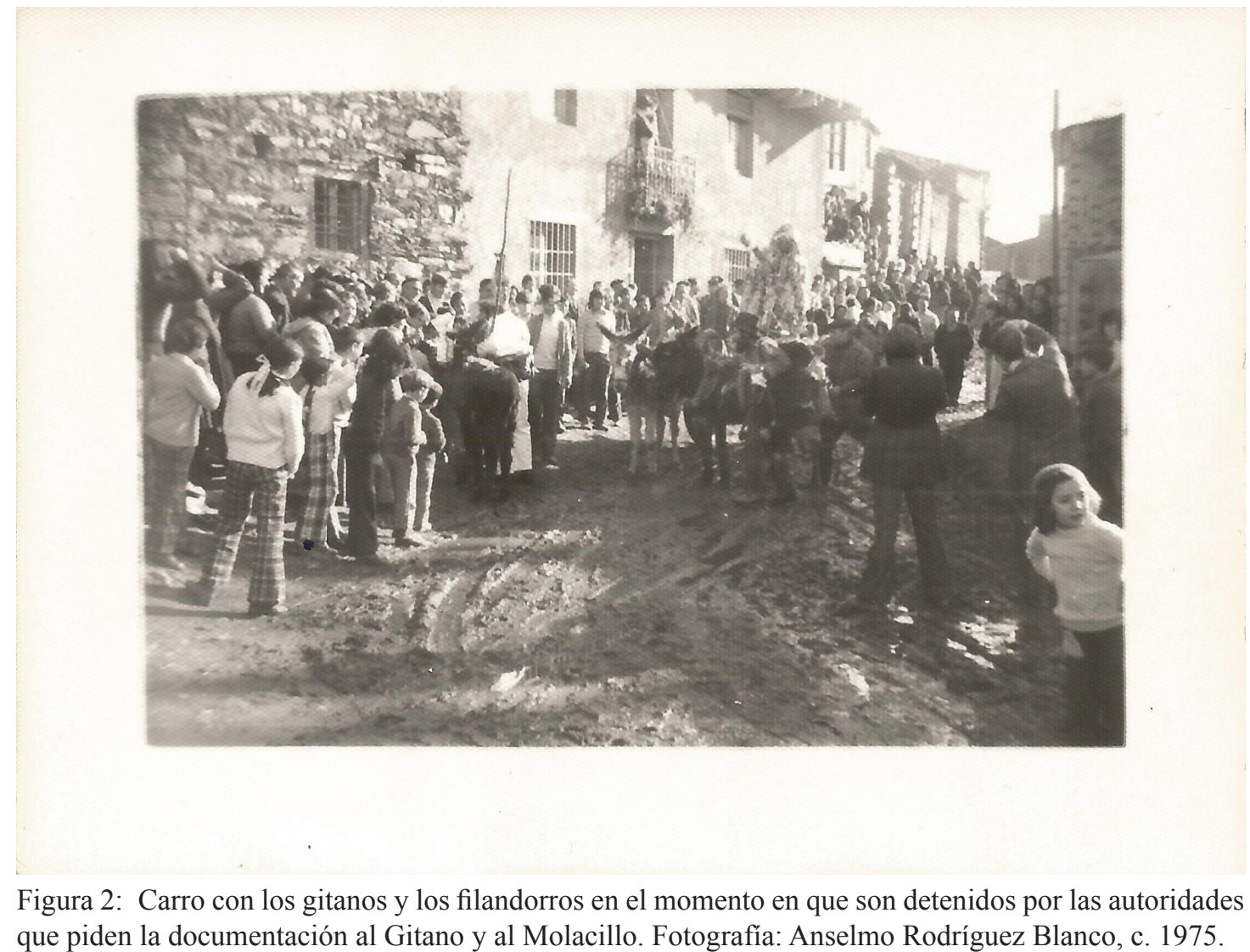




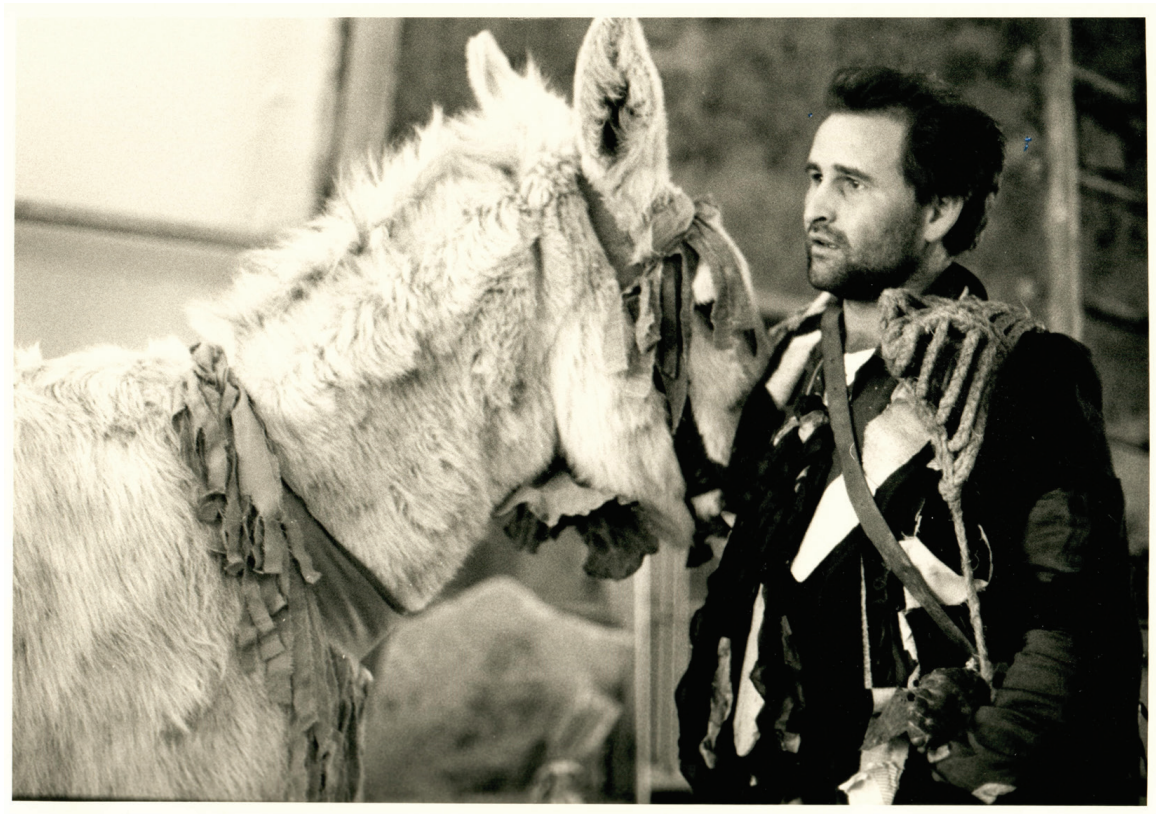

Figura 3: El Gitano con su primer traje y su burro. De él depende en gran medida el éxito de la pre-teatralización. Fotografía: Isaac Macho Blanco, 1993.

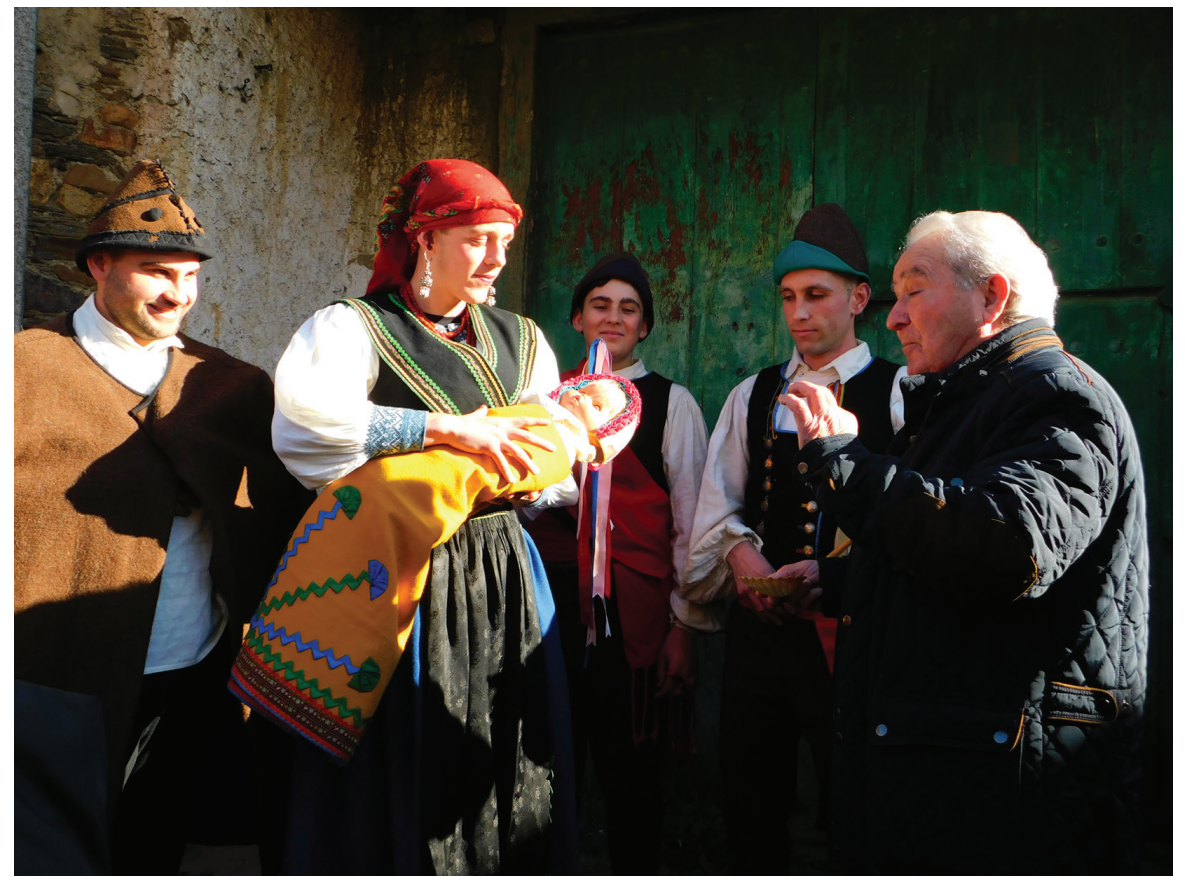

Figura 4: Bautizo del Niño de la Madama. Fotografía: Pilar Panero, 2020.

Gitano dejan sus trapicheos y se duelen de la muerte del Ciego y a partir de ahí comienza la parte más soez y grotesca de la mascarada (Figura 6). Por un lado, intentan aliviar al moribundo y por otro le hacen todo tipo de perrerías, tras las que buscan a un médico entre el público hasta que dan con uno, por supuesto, fingido para continuar con la misma dinámica de ultrajarlo para que sane. Cuando se han ensañado con el pobre malherido y son conscientes de que el «equipo médico» no obtiene resultado, y después de haber maleado al Ciego sin medida, sus compañeros gitanos buscan a un cura entre el público que le de auxilio espiritual en sus últimos momentos, que también es de pega. Se repiten 


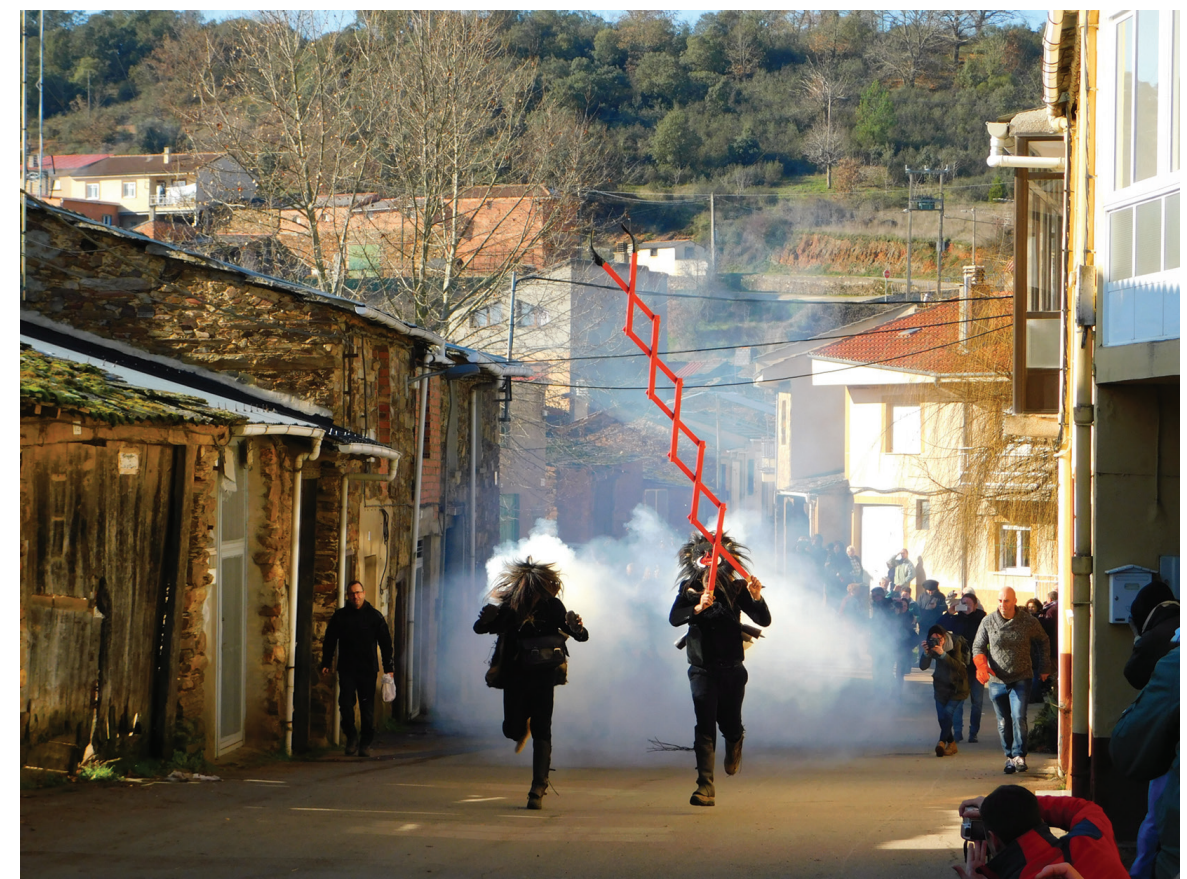

Figura 5: El Carocho Grande hace sus primeras apariciones con el humo de un cohete. Fotografía: Pilar Panero, 2020.

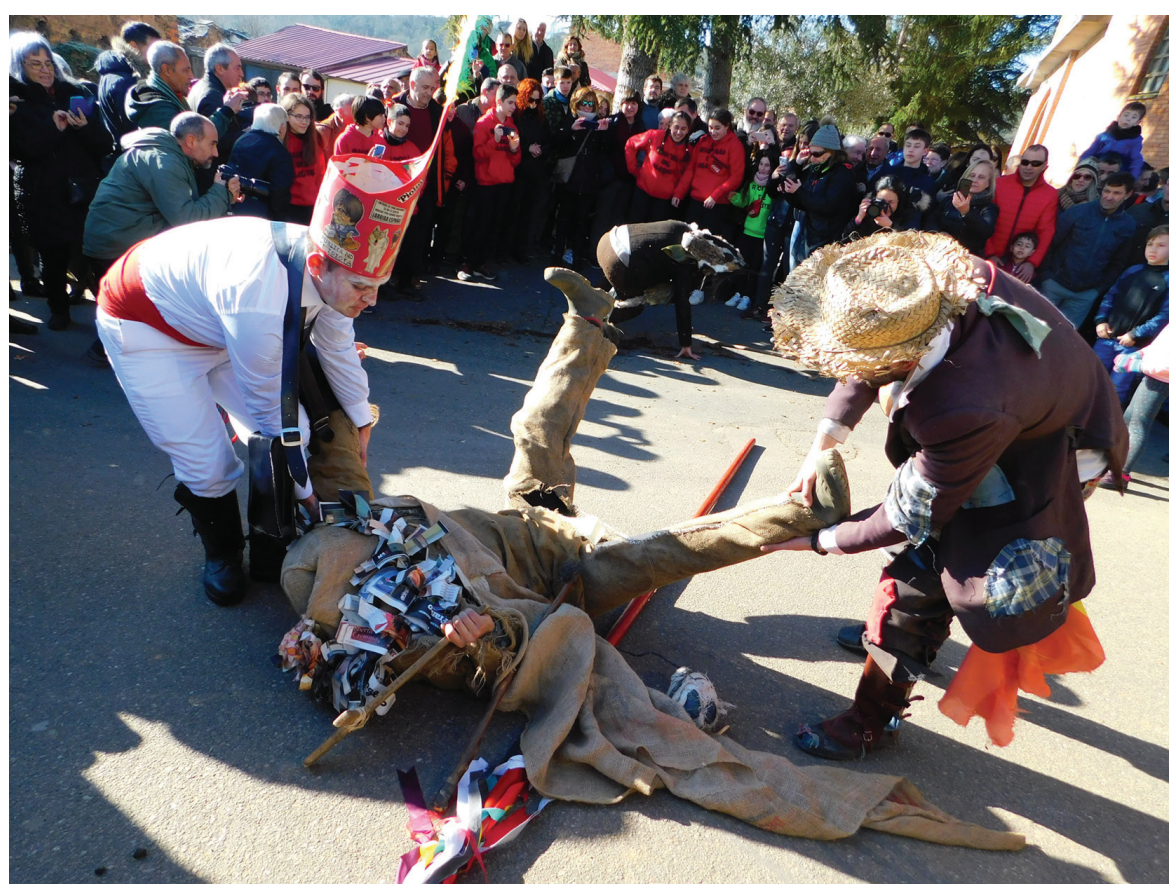

Figura 6: El Molacillo y El Gitano asisten a su manera al Ciego malherido. Al fondo está El del Lino molestando al público femenino. Fotografía: Pilar Panero, 2020.

los disparates y las chocarrerías con El Ciego tendido. Aparece La Filandorra con su traje de papel corriendo en círculo alrededor del enfermo y esparciendo ceniza en el corro que forma la gente congregada. Repite esta operación numerosas veces repartiendo también una buena dosis de ceniza sobre el público. El Gitano con su pelota remarca el círculo de cernada que ha dejado su compañera. Las acciones de los gitanos las define con precisión el romance de Agustín Rodríguez: 


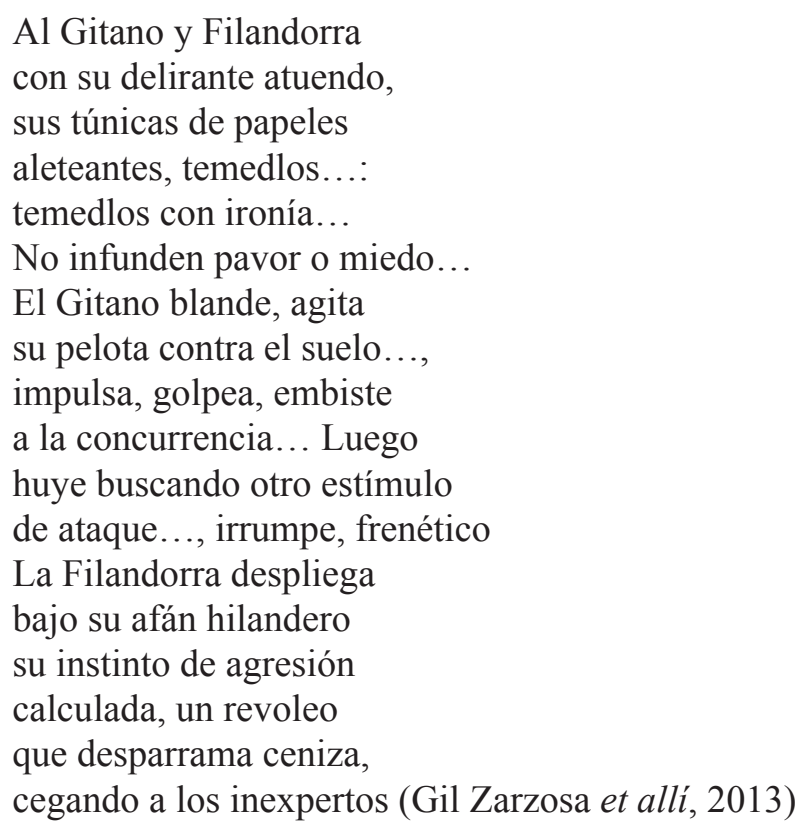

Mientras esto sucede El del Lino está a lo suyo, molestando al público femenino ya sin reparos, pues no le importa que las acosadas sean jóvenes o viejas. Entonces hacen su aparición los diablos atacando al Ciego, el Grande con las tenazas y el Chico tiznándolo con las corchas. Ante la agresión de los diablos, el moribundo se incorpora mostrándoles la cruz de gamón (Figura 7). El Molacillo y El Gitano acuden al auxilio del compañero encarándose respectivamente con El Carocho Grande y El Carocho Chiquito con sus

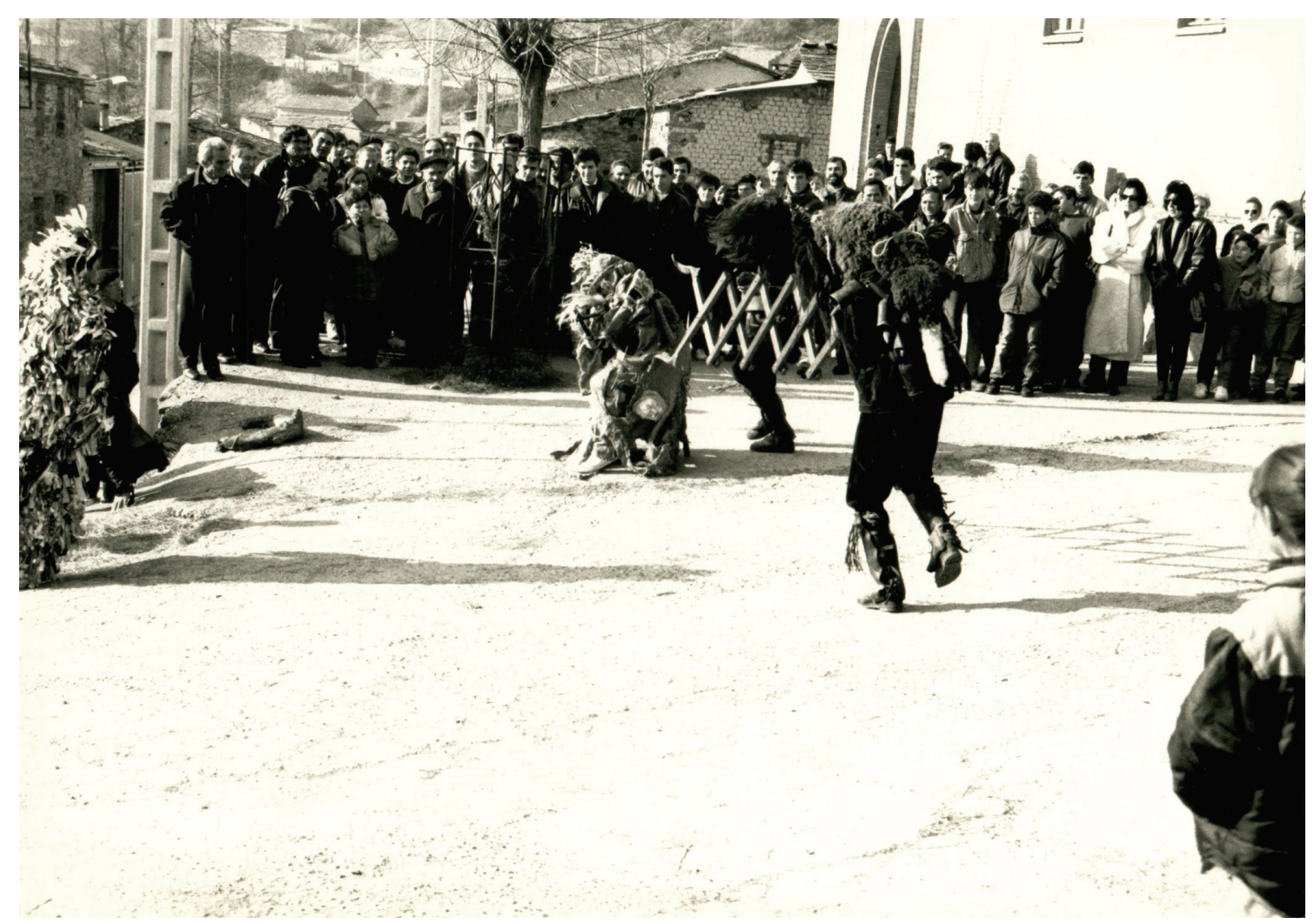

Figura 7: Primer ataque de la mascarada. En la actualidad discurre igual. Fotografía: Isaac Macho Blanco, 1993. 


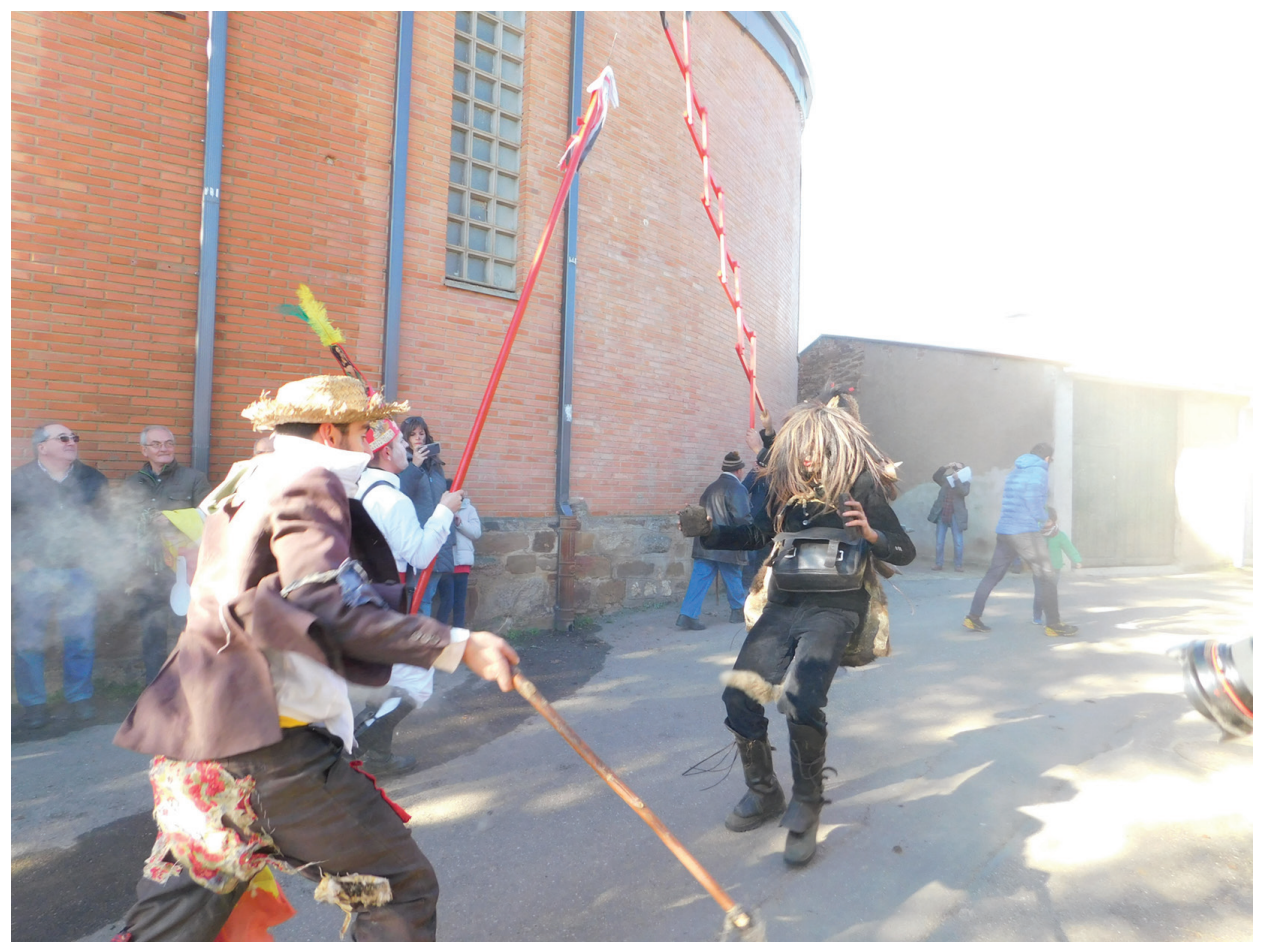

Figura 8: Defensa de los compañeros del Ciego con la pica, la ceniza y la pelota. Fotografía: Pilar Panero, 2020.

armas, la pica y la pelota (Figura 8). Los gitanos vencen y los diablos huyen siguiendo a los guapos. Después de esta primera pelea se inicia la ronda de los diablos y los guapos para pedir el aguinaldo casa por casa.

El Molacillo y El Gitano buscan a su pariente, que ha resucitado y desaparecido, por los lugares más desconcertantes con la ayuda inestimable del público que, como es preceptivo en estas representaciones, les da señas falsas. Se producen de nuevo diálogos hilarantes hasta que El Molacillo cansado toca su cuerno, pero El Ciego tarda en aparecer hasta que, finalmente es capturado y entregado con una soga atada a su cuello. Sus tres compañeros celebran su hallazgo bailando y cantando. El Molacillo toca las conchas y canta coplas picantes y satíricas, sobre las que hablaremos más adelante, acompañado por El Ciego que toca la zanfona, mientras El Gitano y La Filandorra bailan «agarrao», hacen cabriolas, ruedan por el suelo.... El cuadro se presenta de una manera cómica en la que de vez en cuando interpelan al público para que participe o este lo hace de forma espontánea (Figura 9). Cuando terminan inician el recorrido que ya han hecho los otros grupos para pedir el aguinaldo. En cada casa La Filandorra toca a la puerta con el mayo, un martillo de madera grande. Los grupos piden el aguinaldo con unas formulas establecidas, que también explicaremos más adelante, por separado. Antes comían solo en la casa de los familiares, pero ahora los vecinos se ofenden si no prueban algo en sus casas, «un muerdo y una pinta», por lo que la cuestación se demora un poco más (Figuras 10 y 11).

Sin embargo, se ha reducido el número de peleas entre los carochos y los filandorros, pues antes cuando coincidían en una calle se enzarzaban en una nueva pendencia. Ahora tienen la segunda pelea cuando coinciden en la calle de Los Molinos. Mientras piden el Diablo Chiquito entizna con las corchas y La Filandorra esparce ceniza a cuantos 


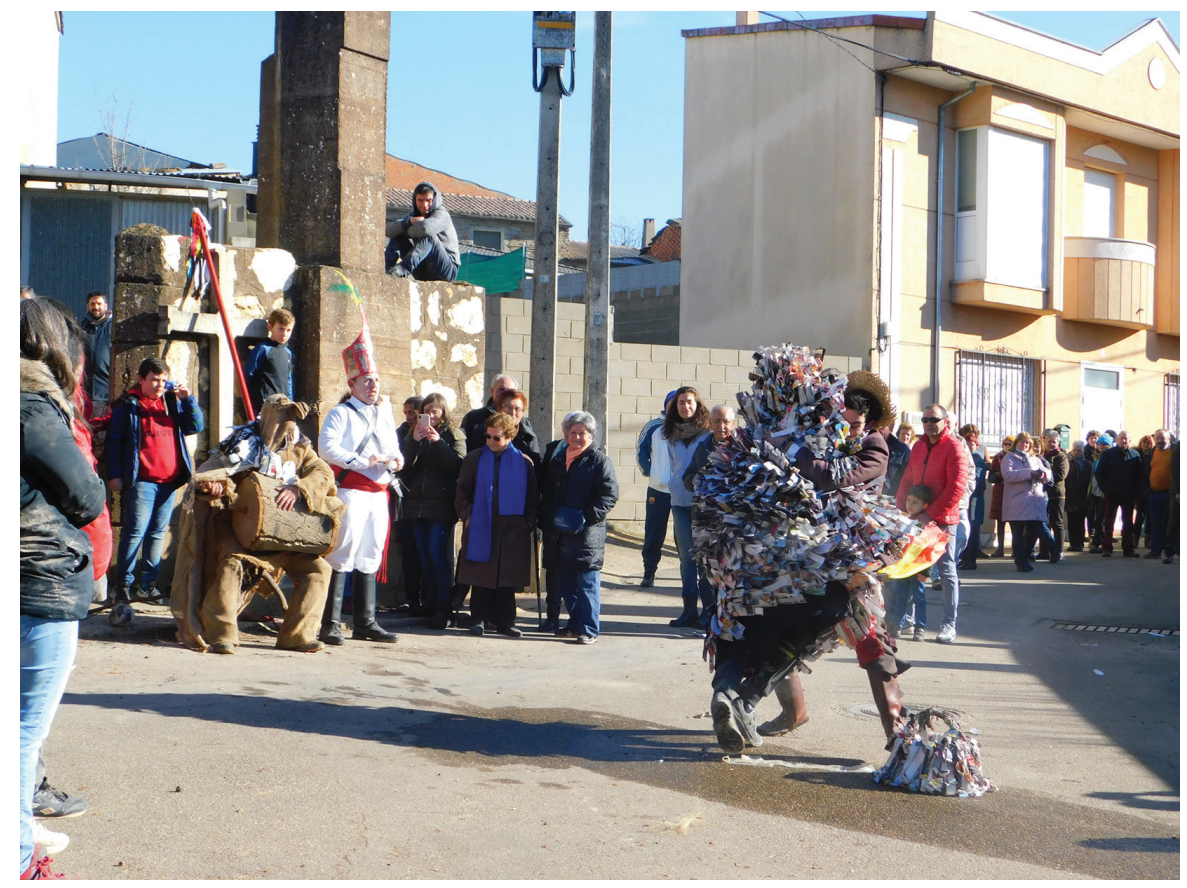

Figura 9: El Molacillo canta y toca las conchas, El Ciego toca el «corcho» y El Gitano y la Filandorra ejecutan su baile estrafalario. Fotografía: Pilar Panero, 2020.

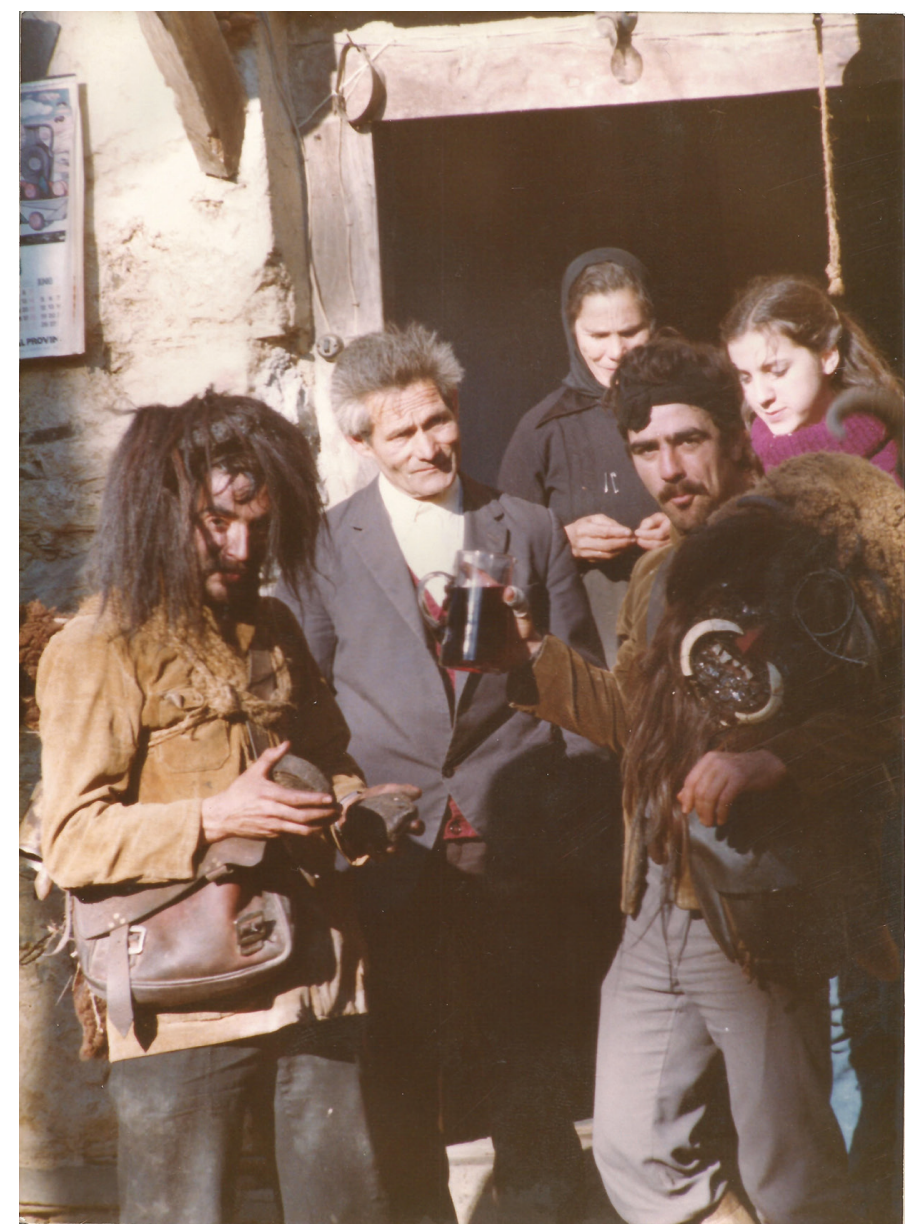

Figura 10: El Carocho Chiquito y el Grande pidiendo el aguinaldo en una casa. Fotografía: Anselmo Rodríguez Blanco, años 70. 


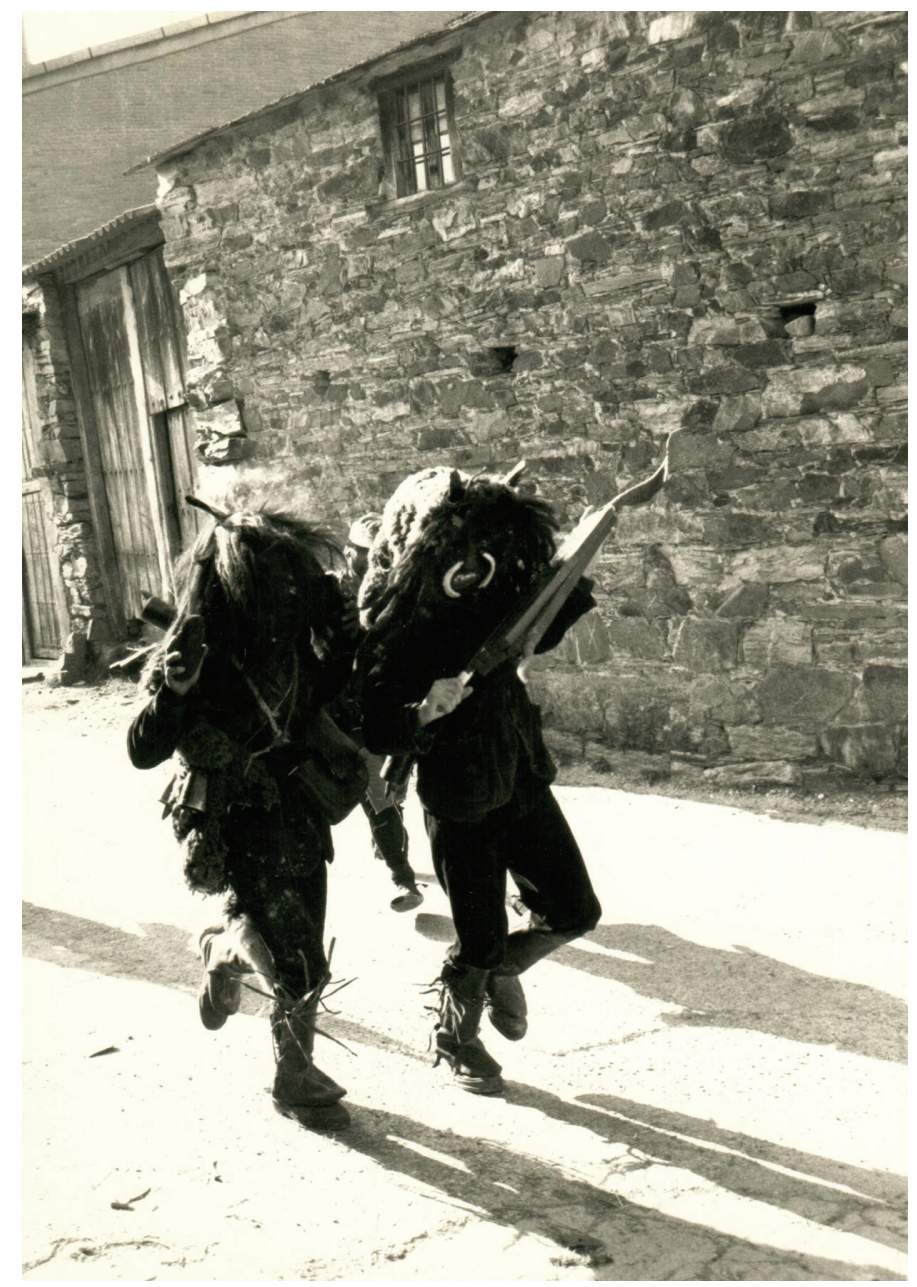

Figura 11: Los carochos recorriendo el pueblo, todavía se conserva parte de la arquitectura vernácula. Fotografía: Isaac Macho Blanco, 1993.

se dejan, especialmente a las mozas y chiquillería. Después de la pelea los carochos atraviesan el río Frío o Becerril (Figura 12). Los grupos continúan con su cuestación y a primera hora de la tarde de juntan de nuevo en el «Sagrao» donde bailan con el público al son de la gaita y el tamboril, los carochos solo saltan haciendo sonar los cencerros sin seguir el paso. Los diablos dan de comer chorizo a los presentes. Se produce un nuevo ataque al Ciego y los filandorros vuelven a acudir en su auxilio (Figuras 12 y 13). La pelea termina como las otras, pero esta vez los carochos son expulsados a las eras hasta el próximo año.

\section{LA ORALIDAD}

En la celebración de Los Carochos prevalece la acción sobre la palabra, pero existen varios momentos en los que los interpretes de los cuadros y los otros participantes, el resto de la comunidad y los espectadores ocasionales, hablan, cantan o dialogan. Estos momentos son: en primer lugar, la solicitud de permiso de los distintos grupos a las autoridades; después, el bautizo del hijo de La Madama; en tercer lugar, las acciones que se suceden con la «muerte» del Ciego; en cuarto lugar, las fórmulas petitorias del aguinaldo; y, por último, cuando El Molacillo canta sus versos. 


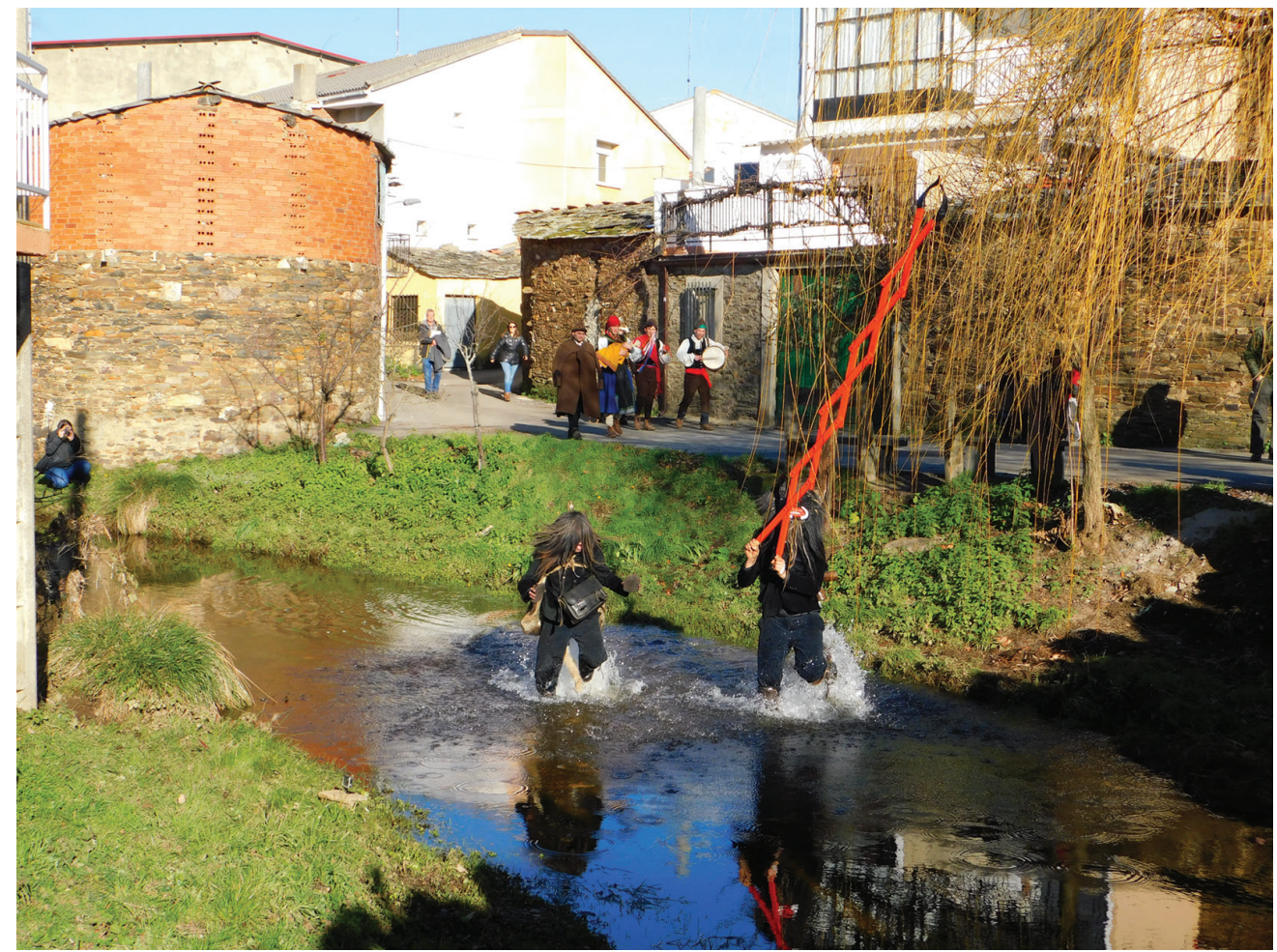

Figura 12: Los carochos atraviesan el río Frío en un rito de purificación. Detrás de ellos los guapos que continúan recorriendo el pueblo pidiendo el aguinaldo. Fotografía: Pilar Panero, 2020.

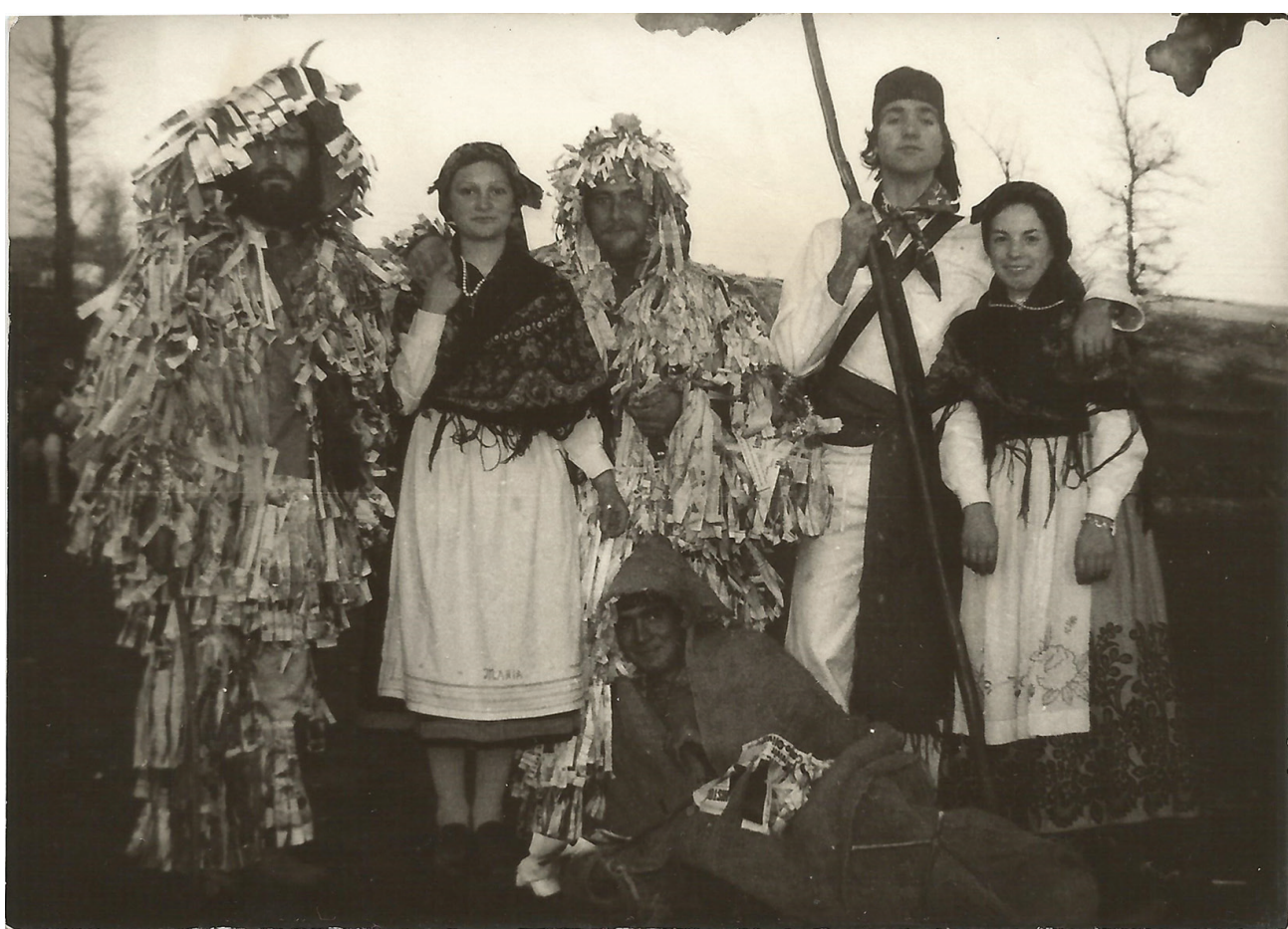

Figura 13: El Gitano con el segundo traje, La Filandorra, El Molacillo y El Ciego en el suelo acompañados con dos chicas preparadas para el baile en el «Sagrao». Fotografía: Anselmo Rodríguez Blanco, c. 1975. 
Es probable que la petición de permiso tuviese fórmulas establecidas, que están recogidas en diversos textos alistanos por Gregorio Rodríguez Fernández (Blanco González, 2004: 174), pero hoy no queda rastro de las mismas y la solicitud se hace de una forma breve, simple y espontánea.

Queda la fórmula del bautismo, que es la que se emplea en los reales, pero, si en la parte que concierne al sacerdote funciona, los jóvenes que han interpretado a los guapos en 2020 apenas han interactuado con el cura, probablemente porque gran parte de la juventud hoy día desconoce este rito. El diálogo es pobre y prácticamente se limita dar la bienvenida a los padres y padrinos por parte del sacerdote, los padres dicen cuál es el nombre y el sacerdote derrama agua la cabeza del Niño con las palabras "yo te Bautizo en el nombre del Padre, del Hijo y del Espíritu Santo» y su bendición. Se omiten partes esenciales como cuando los padres confirman porque quieren que sea bautizado, la ayuda de los padrinos en su educación en la fe y las renuncias a Satanás que ahora muchas personas simplemente desconocen. Pensamos que en este asunto son pertinentes las siguientes palabras de Luis Díaz Viana (1984: 17):

la Tradición Oral no es sólo un modo de comunicación de conocimientos sino también continua recreación de los materiales con los que ésta o aquella comunidad se identifican, se educan y se divierten. Hay, en la relación entre el grupo de gentes y su Tradición Oral, un perpetuo reacoplamiento: la Tradición Oral caracteriza y define muchos de los comportamientos y creencias del grupo y éste a su vez va transformando esa tradición según su propia evolución social y económica; según las presiones y cambios a que se ve sometido.

La modernización ha avivado la secularización, pues las restricciones sociales asociadas a esta ceremonia se han vuelto laxas o menos sacralizadas, entendiendo que lo sagrado es la relación humana con la ritualidad, con cualquier ritualidad que puede coincidir con la religión católica o no.

Sí se mantiene una comunicación dinámica, directa y presencial entre el grupo de los filandorros y el público cuando los primeros intentan venderles sus mercancías y bienes y, también cuando intentan sanar al Ciego con el médico de pega y, después, aliviarlo espiritualmente con el falso cura. Para que el cuadro funcione es preciso que los personajes (emisores) tengan la complicidad mediante el oído y la vista por el público (receptores), que en algún momento pueden intervenir, porque la recepción es colectiva y participativa de modo que puede influir en la duración y, por supuesto, en el desarrollo de la comunicación. Los personajes de la mascarada se adaptan a su público. Existe una memoria local y también individual, que propicia que, aunque con variantes y en función de la imaginación de los personajes y de lo espontáneos que sean, al conectar con el público el discurso sea efímero. Sin embargo, esto no impide que ese discurso fugaz se apoye en recursos diferentes a la literatura y propios de la retórica de la oratura pensando en «cosas memorables»:

para resolver eficazmente el problema de retener y recobrar el pensamiento cuidadosamente articulado, el proceso habrá de seguir las pautas mnemotécnicas, formuladas para la pronta repetición oral. El pensamiento debe originarse según pautas equilibradas e intensamente rítmicas, con repeticiones o antítesis, alteraciones y asonancias, expresiones calificativas y de tipo formularia, marcos temáticos comunes (la asamblea, el banquete, el duelo el «ayudante» del héroe, y así sucesivamente), proverbios que todo 
el mundo escuche constantemente, de manera que vengan a la mente con facilidad, y que ellos mismos sean modelados para la retención y la pronta repetición, o con otra forma mnemotécnica (Ong, 2016: 78).

La conexión con el público que potencialmente es también actor y, en buena medida, determina el ritmo de la acción y del diálogo se complementa con el volumen, la entonación, las pausas frente a la acción y los gestos. La originalidad no está en que la historia sea nueva, sino en «lograr una reciprocidad particular con el público en ese momento» (Ong, 2016: 88). Este cuadro dinámico y, en general, disparatado, se complementa con El del Lino haciendo de las suyas a las mujeres y La Filandorra esparciendo la cernada sobre todos los incautos. Estos dos personajes sumados al Ciego moribundo, pero que de cuando en cuando se mueve, El Gitano y El Molacillo lamentándose de la suerte de su pariente y buscando remedios de los más peregrinos generan el caos y el público así lo percibe.

La petición del aguinaldo de los personajes de la obisparra también se ha simplificado en los últimos años acomodándose a los usos actuales, aunque la fórmula que dictaba la costumbre, que se iniciaba con una felicitación por el Año que comenzaba, está perfectamente registrada (Rodríguez Pascual, 2009: 137):

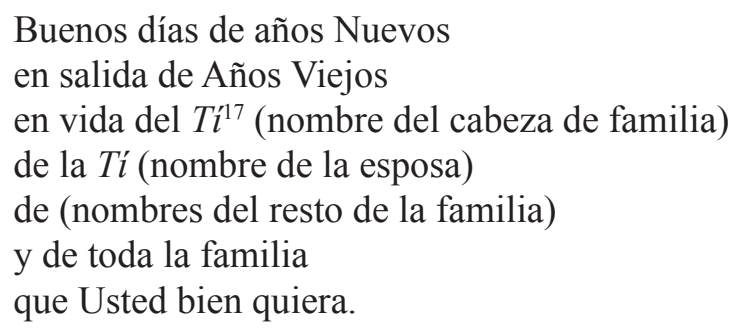

Cuando la familia visitada otorga los presentes - productos de la matanza, dulces, otras viandas o dinero- a los distintos grupos, los anfitriones hacían una primera despedida con la fórmula consuetudinaria: «Que de hoy en un año». Más adelante, cuando los mozos ya estaban saliendo a la calle el dueño de la casa decía «Ala, que tengáis salud para hacerlos muchos años», parabién al que los jóvenes contestaban con igual cortesía, «Y usted para verlos» (Blanco González, 2004: 201). Estos brindis se mantienen en 2020, aun considerando que puede haber ligeras variantes en función de los interlocutores.

La fórmula principal, "Que de hoy en un año», se puede comprender bajo las «coordenadas de fertilidad y conjuro que no se interfieren, sino que se complementan» y expresaría, «junto con el deseo de salud y prosperidad, el propósito de continuidad dentro de una tradicional estructura» (Díaz Viana, 1984: 126 y 133). Esta fórmula está muy extendida y se utiliza en muchos ritos y, de hecho, la misma, sirve para marcar la pauta y emplazar a algo obligatorio y simbólico que se debe repetir, porque de su correcta ejecución en el tiempo estipulado se derivaran unas consecuencias concretas. Si el rito se hace conforme a lo establecido serán beneficiosas pues tiene un valor social y de ahí, la insistencia en emplazar al tiempo cíclico que marca la tradición ${ }^{18}$.

El Molacillo canta los versos a ritmo de jota y percutiendo las conchas y es ayudado por El Ciego, que como hemos dicho, tras su milagrosa resurrección y desaparición toca la zanfona. Estas canciones, como se llaman en Riofrío, en general son

\footnotetext{
${ }^{17}$ Tí es apocope de «tío» o «tía» y en Aliste es el tratamiento de gran respeto a los mayores todavía hoy día.

${ }^{18}$ La fórmula da título a la monografía de Luis Díaz y José M. ${ }^{a}$ Martínez (1992).
} 
octosílabos, pero con algunos metros fluctuantes, ofrecen dos posibilidades. O bien este personaje canta algunas coplas ya escritas y fijadas que memoriza, o bien canta otras que él compone cada año en función de los acontecimientos, locales, regionales, nacionales o internacionales que hayan sucedido en el que termina de concluir. Si los primeros versos son conservadores de la tradición, los segundos son una dramatización transgresora de la experiencia colectiva que opera como expresión verbal de preocupaciones o anhelos vitales, que también expresa con las fotografías, dibujos y textos con los que decora su morrión ${ }^{19}$. El tono de las mismas es arrabalero, con contenido sexual implícito en muchas de las que se cantan, porque este grupo de los filandorros mantiene la línea cómica por lo que recurre en sus letras al equívoco. Al son de las coplas El Gitano y La Filandorra ejecutan su baile soez y estrafalario.

Algunas de las coplas del repertorio popular están recopiladas (Blanco González, 2004: 189-196; Rodríguez Pascual, 2009:133), pero trascribimos solo las que cantó El Molacillo este 2020 entre las que intercalaba su grito característico al finalizar cada una y sus chascarrillos:

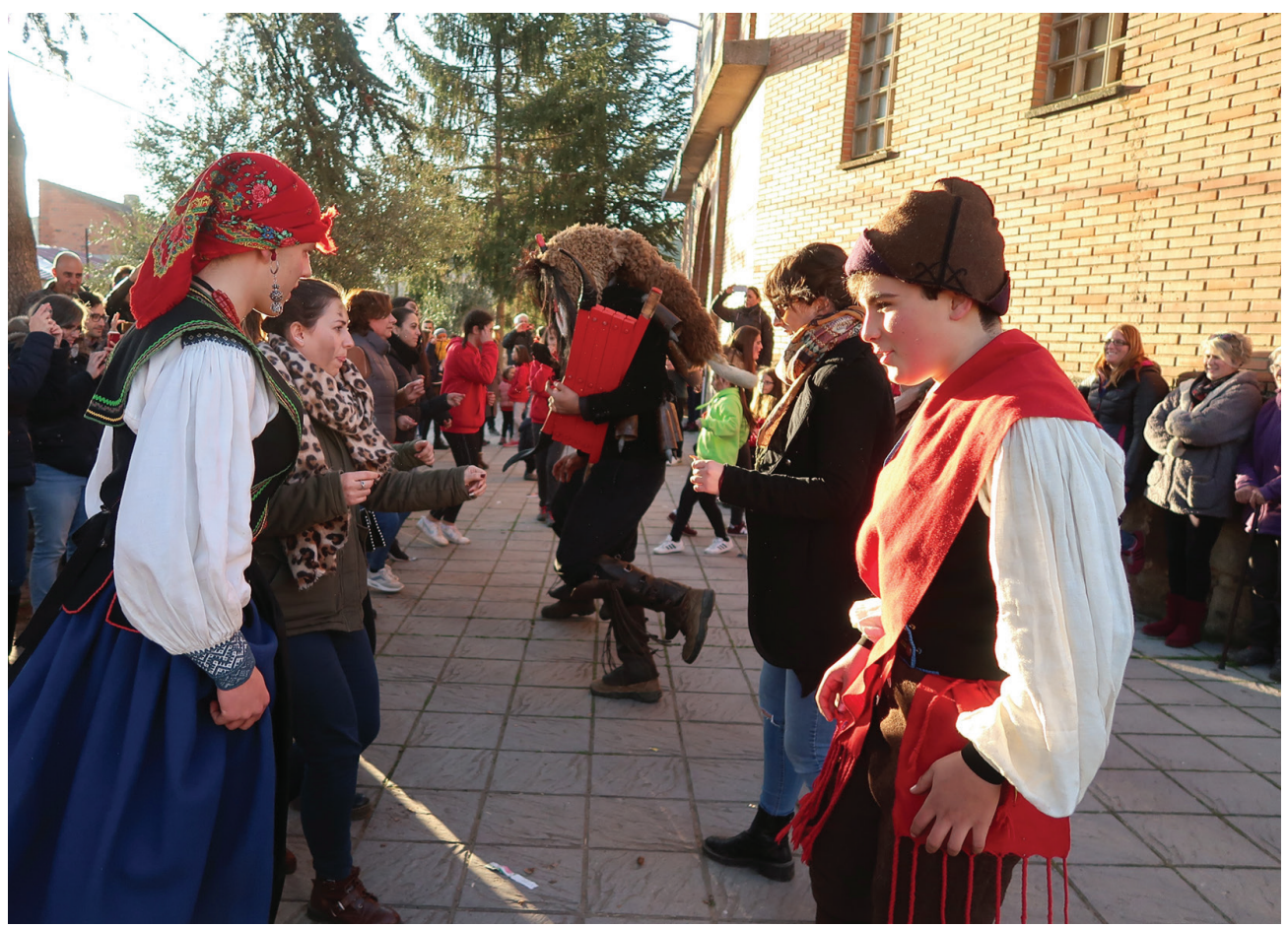

Figura 14: Baile de todos los personajes. Después los carochos darán chorizo a la gente y tras la última pelea son expulsados hasta el año siguiente. Fotografía: Isaac Macho Blanco, 2020.

${ }^{19}$ En el de 2020, además del año, imágenes eróticas que reflejan el carácter lascivo de los filandorros y el lema «Somos Carochos» se decoró con: una caricatura de Carles Puigdemont y el texto «La república no existe. Imbécil»; una imagen de Oriol Junqueras entre rejas con un bocadillo en el que se decía «De verdad, que no te estoy guiñando el ojo»; la palabra «Cataluña» y una estelada con forma de pendiente pronunciada y un coche precipitándose; y otra imagen de Oriol Junqueras corriendo con ropa deportiva al lado de la de un lobo, un animal representativo de Aliste, y el texto «Entras en zona nacional. Si no te gusta vuélvete por donde viniste. ¡Arriba España!». El morrión refleja el hartazgo de gran parte de la ciudadanía española con un problema que, lejos de solucionarse para ninguna de las partes, cada vez está más enquistado y genera tensión de forma exponencial, y condiciona el desarrollo político, social y económico de España.

Otros años lo han decorado con expresiones como « No al silencio de los curas!», en alusión a los casos de sacerdotes pederastas, «despoblación», caricaturas de personajes como el comisario Villarejo... 
En el alto Los Castricos (bis)

hay una inmensa laguna.

Donde se lavan las feas (bis)

porque guapa no hay ninguna.

A la harina, harina

y al salvao, salvao.

$\mathrm{Y}$ al pimiento picante

colorín, colorao. (bis)

A la harina, harina

y al salvao, salvao.

II

En la tierra La Devesa (bis)

hay más corzos que buen trigo.

Cuando vas con la escopeta (bis)

no aparece ningún chivo.

Por la sierra de abajo corren las liebres.

Las zorras y las lobas por Alcañices

Por Alcañices niña, por Alcañices

Por la sierra de abajo corren las liebres.

III

Una vieja en un corral

estaba asando un conejo,

le entró una chispa pal culo

y mandó a tocar concejo.

Arrepún que te meto

son tres lugares:

Puerto Rico, La Habana y Buenos Aires.

Y Buenos Aires, niña

y Buenos Aires.

Arrepún que te meto

son tres lugares.

IV

En el cielo manda Dios (bis)

en el campo los gitanos

y en el pueblo de Riofrío (bis)

el hijo del Ti Maximiano.

El del Ti Maximiano se va a emborrachar

En las fiestas de agosto con la ginebra

con la ginebra, niña, con la ginebra

en las fiestas de agosto se va a emborrachar.

$\mathrm{V}$

Las mocitas de Riofrío (bis)

van todas por un canal 
Las de adelante van preñadas (bis)

Y las de atrás van pa la capital.

En Riofrío no quedan mozas pa criar.

Esto es un problema que hay que solucionar. (bis)

En Riofrío no quedan mozas pa criar.

Aunque algunas coplas, aunque sea parcialmente, están escritas, no podemos hablar propiamente de textos. Es cierto que se han fijado en un momento con la escritura, ahora también lo estamos haciendo, pero al oralizarlas, además de que se pueden combinar así o de otras muchas maneras y modificarlas ${ }^{20}$, son parte de la pre-teatralización. Las coplas funcionan dentro del complejo ritual en función de quien las ejecuta, pero también de quien las recibe. Las reacciones del receptor son tan importantes como el mensaje del emisor, porque ambos se alimentan y complementan. Muchos contenidos solo se entienden en clave local, por ejemplo, la IV, que alude al alcalde, que, aun siendo abstemio se le tilda de borracho para gastarle una broma con sus paisanos.

En las coplas, al margen del contenido obsceno, escatológico y jocoso propios de muchas canciones del ciclo de Carnaval (Campo Tejedor, 2018), se tratan temas importantes para la comunidad, para su bienestar y su cohesión social. Por ejemplo, en la II se alude al crecimiento descontrolado de la fauna salvaje — jabalíes, corzos y ciervos - que son un peligro real para las cosechas en las que provocan destrozos y para los conductores, por el gran número de accidentes de tráfico que provocan. La $\mathrm{V}$ alude a la trágica atonía demográfica con un crecimiento vegetativo negativo.

Uno de los tópicos en torno al Carnaval, en general, es considerarlo una destruccióntransgresión simbólica del orden establecido. Esta afirmación carece de valor en los carnavales urbanos subvencionados (Marcos Arévalo, 2009: 5-6), e incluso si pensamos en los rurales como las mascaradas cuando están encapsulados en los desfiles-espectáculo, pues aquí el Carnaval es aliado del poder político-económico. Sin embargo, sí pensamos que el tópico que se repite por inercia, no es tal en muchas mascaradas que mantienen algunos elementos del Carnaval histórico. Este mantiene su función crítica hacia todo lo que la comunidad considera que es maléfico o perjudicial, sin menoscabo de los cauces que para la misma tienen las sociedades democráticas. El histrionismo y la risa son parte de la puesta en escena, pero estas no merman el carácter cívico y moralizante de las coplas como sucede en otros lugares como en el «entierro de la zorra» en varias comunidades granadinas (Fernández Cuesta, 1988), «as loas» en Varge, «as comédias» de Aveleda, «os colóquios» en Baçal y en otros lugares de Tras-os-Montes (Tiza, 2018:87-98) y, también, en las coplas que se cantan en la vecina Abejera, etc.

En una composición de hace unos años se critica la avaricia de algunos vecinos que, cuando se empezó la concentración parcelaria, les faltó tiempo para recoger los desechos de madera para su consumo sin esperar a que la empresa adjudicataria los repartiera hermanamente entre todos:

Ya están hechos los caminos (bis)

y la leña ya no está

y en algunos cabañales (bis)

cada día tienen más.

${ }^{20}$ En I existe la variante «guapas» por «feas» $\mathrm{y}$ «fea» por «guapa», en III «guisando» por «asando», etc. 
¡Todo cristo a por leña!, que hay que trabajar los tractores con leña ya no pueden más ya no pueden más, niña, ya no pueden más, los tractores con leña ya no pueden más.

En otra composición se refieren al descontento con el ingeniero responsable de la concentración parcelaria, no solo con el resultado, sino también con la demora:

\author{
Ya nos llegaron las tierras (bis) \\ después de unos cuantos años \\ y este hijo de su madre (bis) \\ nos ha dao todo barrancos. \\ Si no hubieras venido \\ estaríamos igual, \\ Pero sin marcos, niña, \\ pero sin marcos.
}

También se ataca con dureza a aquellos que, aun amparados por la ley, actúan de forma poco ética usurpando bienes comunitarios y arremetiendo contra lo que otorga el derecho consuetudinario. Se han hecho coplas criticando a un sacerdote, que aun siendo natural de Riofrío, fue expulsado por apoyar a su obispo que inmatriculó bienes comprados por el pueblo, lógicamente sin ninguna consulta. La inquina si cabe es mayor en casos así, porque los hijos del pueblo deben conocer el código ético y el derecho de usos o costumbres a diferencia del ingeniero de la copla anterior, que es forastero.

Esta oralidad en está ausente en los medios digitales en los que la imagen, sin embargo, es omnipresente. No estamos afirmando que no pueda aparecer algún dato concreto, pero si aparece, es de forma anecdótica y supeditado, al poder de la imagen estereotipada de lo diabólico, lo zoomorfo (cornamentas, pieles de animales, cráneos, fauces...), lo estrafalario de los acompañantes de los enmascarados y todos sus atributos para la agresión, pero el único sonido que se suele mencionar es el de los cencerros, más que el de otras músicas que acompañan. Internet es un espacio para la exhibición de las mascaradas, pero con respecto a la oralidad - composiciones anónimas o no, breves y sencillas, que perviven en la memoria, aunque se fijen por escrito, y que mezclan lo serio y didáctico con soez y jocoso- es un espacio de ocultación.

\title{
SIGNIFICACIÓN RITUAL Y CONSIDERACIÓN ACTUAL
}

Los Carochos son una dramatización dinámica de una experiencia colectiva de los vecinos de Riofrío en el pasado operaban en una sociedad autárquica y, desde su recuperación en los años 70, sigue siendo la experiencia de los que todavía moran allí más los que están fuera por diversas razones, como miembros de una sociedad global en la que la tradición no es un monopolio de grupos estancos.

Las ceremonias en el pasado estaban relacionadas con los ritos de iniciación o paso (la organiza el colectivo de mozos), con los ritos de la fecundidad y la sabiduría (reparto de parabienes, petición de aguinaldos, niño recién nacido, obscenidad, démones que regresan en el solsticio de invierno), con ritos de purificación y purga mediante el fuego (expandir el humo, arrojar ceniza y tiznar con la corcha), la palabra (pronunciar fórmulas y recitar coplas satíricas) y el agua (bautizar al Niño y cruzar el río) y, también, 
con ritos de lucha de los opuestos (todas las peleas agónicas de grupos contrarios utilizando instrumentos para agredir). Todavía en Los Carochos se manifiestan estos tipos de ritos que podemos interpretarlos de dos maneras, como supervivencias puras, y aquí aplaudiríamos su resistencia al cambio sin más; o como supervivencias populares en un proceso cultural híbrido y complejo (García Canclini, 1995: 205), si consideramos que la mayor parte de los participantes hoy han desarrollado la mayor parte de su vida en la ciudad y, lógicamente sus quehaceres no se ordenan con el tiempo natural (astronómico-metereológico) de las sociedades agroganaderas de las que proceden estos ritos esenciales.

Sin embargo, en el tiempo cultural extraordinario la fiesta se percibe por sus cualidades diferenciadoras en las que prima una vinculación a la tierra de origen, no solo como un lugar geográfico-natural al que retornar, sino como un lugar social, personalizado donde todos conocen la ascendencia de todos a diferencia de lo que ocurre en la ciudad. A pesar de esta perspectiva emic, desde un punto de vista etic la comprensión de Los Carochos, y de las otras mascaradas, solo se puede entender desde el relativismo cultural, ajeno a planteamientos etnocéntricos. De hecho, todos los cuadros de la pre-teatralización se resuelven de una manera airosa para todos y el final suele ser, como sucede en este caso, una apoteosis de la unión de la diversidad.

Esta complejidad ha sido aprovechada en los últimos años por aquellos integrantes de la comunidad, que consideran que tienen una responsabilidad pública con respecto a la tradición heredada. Estos, sin anular el rito y todos los elementos espontáneos que lo conforman, lo compaginan con otras acciones más mediáticas como los desfiles, que tienen una amplia repercusión en Internet. También aprovechan la Web oficial, para difundir la mascarada tal y como se vive cada uno de enero en Riofrío y que, al mismo tiempo, sea una historia de vida, y todas aquellas manifestaciones artísticas y culturales, e incluso comerciales, que nacen de la misma.

Independientemente de que sea necesario hallar la armonía entre las comunidades, las que ejecutan sus ritos, y las entidades públicas y políticas, las que las instan y subvencionan para construir espectáculos basados en la máscara, pero transformados en productos turísticos. Todavía late una cultura profunda capaz de dinamizar a muchos colectivos con motivaciones diversas. Cualquier reencuentro identitario que se haga hoy día con respecto a esta mascarada o a cualquier otra, sea como rito o como espectacularización de la cultura popular o campesina, necesariamente pasa por las redes sociales, sitios web, blogs... Sin embargo, no parece que fuera del propio rito o de algunas publicaciones en Internet muy concretas, la oratura seria e inconveniente o, simplemente, ocurrente y grosera se exponga como una parte fundamental de la mascarada.

\section{BiBLIOGRAFÍA}

Blanco Albert, Daniel (2017): «Riofrío y Birmingham unidos por la ópera La Obisparra», Los Carochos, 5, pp. 10-11.

Blanco González, Juan Francisco (2004): Los Carochos. Rito y tradición en Aliste, Zamora, Semuret.

Blanco GonzÁlez, Juan Francisco (2020): «El cuerno y la magia del viento», Los Carochos, 8, p. 7.

Blanco Sutil, Jorge (2015): «Periplo a Ítaca, un viaje de ida y vuelta», Los Carochos, 3, p. 9. 
Calles Pérez, Agustina y Ramos García, Carmen (2010): Indumentaria tradicional en Sayago, Zamora, CESIC et alii.

Calvo Brioso, Bernardo (2012): Mascaradas de Castilla y León. Tiempo de fiesta. Junta de Castilla y León. Consejería de Cultura y Turismo. URL: <http://www.jcyl.es/ jcyl/patrimoniocultural/mascaradas/fichas/mascaradas.pdf $>$.

CAmpo Tejedor, Alberto del (2018): «Tiempo para la burla obsceno-escatológica. Las sandingas: fiesta, sexualidad e inversión del orden en un pueblo de Andalucía», Boletín de Literatura Oral, 8, pp. 133-157. DOI: <https://doi.org/10.17561/blo. v8.7

Caro Baroja, Julio (1965) (2006): El Carnaval. Análisis histórico-cultural, Madrid, Alianza Editorial.

Caro Baroja, Julio (1967): Lo que sabemos del Folklore, Madrid, Gregorio del Toro, ed. CARo BARoja, Julio (1978): Las formas complejas de la vida religiosa, Madrid, Akal.

Cotera, Gustavo (1999): La indumentaria tradicional en Aliste, Zamora. Instituto de Estudios Zamoranos «Florián de Ocampo»-Caja España, Zamora.

Díaz Viana, Luis (1984): Rito y Tradición Oral en Castilla y León, Valladolid, Ediciones Ámbito.

Díaz Viana, Luis y Martínez Laseca, José María (1992): «De hoy en un ... año». Ritos y tradiciones de Soria, Soria, Diputación Provincial de Soria.

DueÑas, Arturo (2019): Las mascaradas de Aliste, Valladolid, La Esgueva Films, 18'.

FernÁndez Cuesta, Eliseo (1988): «Hipótesis sobre una función de Carnaval», Gazeta de Antropología, 6, art. 8. <http://hdl.handle.net/10481/13754>

GAGO, Rubén (2016): «Entrevista a Manuel Garrote Blanco, director de Galo, la leyenda de Los Carochos», Los Carochos, 4, pp. 10-14.

García CANClini, Néstor (1995): Culturas hibridas. Estrategias para entrar en la modernidad, Buenos Aires, Editorial Sudamericana.

Garrote Franco, Manuel (2015): «Galo: la leyenda de Los Carochos. Mascarada a 24 fotogramas por segundo», Los Carochos, 3, p. 3.

Gil Zarzosa, Ignacio, Vara Fernández, Esther y Macho Blanco, Isaac (coords.) (2013): Riofrío de Aliste. Nuestra vida, nuestras imágenes 1900-1979, Valladolid, Ediciones Imágenes con vida.

Godinho, Paula (2010): Festas de Inverno no Nordeste de Portugal. Património, mercantilização, e aporías da «cultura popular», Castro Verde-Alentejo, 100Luz.

González Fernández, Óscar J. (2014): Mascaradas de la Península Ibérica, Oviedo, Eujoa.

Hidalgo Blanco, Laura, Chimeno González, Benjamín y José Miguel Canas Morán (2017): «Todos somos carochos», Los Carochos, 5, pp. 4-6.

Hortelano Mínguez, Luis Alfonso (coord.) (2009): Atlas de la Raya hispano-lusa: Zamora/Tras-os-Montes, Zamora, Diputación de Zamora. URL: <http://www. distrans.es/recursos/descargas/atlas-la-raya-hispano-lusa.pdf>

Marcos Arévalo, Javier (2009): «Los carnavales como bienes culturales intangibles. Espacio y tiempo para el ritual», Gazeta de Antropología, 25, 2, art. 49. URL: $<$ http://hdl.handle.net/10481/6906>.

Martí I PÉrez, Josep (1996): El Folklorismo: uso y abuso de la tradición, Ronsel, Barcelona.

Méndez Plaza, Santiago (2002): Costumbres comunales de Aliste, Juan Ignacio Plaza Gutiérrez y Luis Alfonso Hortelano Mínguez (introd.) Zamora, Ayuntamiento de Riofrío de Aliste-Semuret. 
ONG, Walter J., (1982) (2016): Oralidad y escritura: tecnologías de la palabra, México, Fondo de Cultura Económica.

Panero García, M. a Pilar (2017): «Cambio semántico en una mojiganga. La Vaca Bayona de Almeida de Sayago», en Maschera e alterità, Pietro Sisto e Pietro Totaro (eds.), Bari, Progedit, pp. 179-207.

Rodríguez Pascual, Francisco (2009). Mascaradas de invierno en la provincia de Zamora, Zamora, Semuret.

Rodríguez, Alfredo (2014): «Embajadores durante 2013», Los Carochos, 2, p. 4.

SÁnchez Jiménez, José (1975): La vida rural en la España del siglo XX, Barcelona, Planeta.

TızA, António A. Pinelo (2013): Máscara e Danças Rituais - Ritos Ibéricos do Solstício de Inverno, Lisboa, Eranos.

TızA, António A. Pinelo (2018): Simbologia Maçónica nos Rituais de Inverno, Carviçais, Lema d'Origem.

Tola TolA, Roberto (2015): «Las Obisparras de Aliste (Zamora): la celebración del "Pajarico" en Villarino Tras la Sierra a través de una descripción del siglo XVI», Revista de Folklore, 395 (enero), pp. 4-13. URL: <https://funjdiaz.net/ folklore/07ficha.php?id=3952>.

Fecha de recepción: 10 de febrero de 2020

Fecha de aceptación: 14 de marzo de 2020

$$
9
$$

